\title{
Counteranion-Dependent Reaction Pathways in the Protonation of Cationic Ruthenium-Vinylidene Complexes
}

\author{
Manuel Jiménez-Tenorio,* M. Carmen Puerta,* and Pedro Valerga \\ Departamento de Ciencia de los Materiales e Ingeniería Metalúrgica y Química Inorgánica-INBIO, Facultad de Ciencias, Universidad \\ de Cádiz, 11510 Puerto Real, Cádiz, Spain
}

Manuel A. Ortuño, Gregori Ujaque, and Agustí Lledós*

Departament de Química, Universitat Autònoma de Barcelona, 08193 Cerdanyola del Vallès, Barcelona, Spain

Supporting Information

\begin{abstract}
The tetraphenylborate salts of the cationic vinylidene complexes $\left[\mathrm{Cp} * \mathrm{Ru}=\mathrm{C}=\mathrm{CHR}\left({ }^{\mathrm{i}} \mathrm{Pr}_{2} \mathrm{PNHPy}\right)\right]^{+}(\mathrm{R}$ $=p-\mathrm{C}_{6} \mathrm{H}_{4} \mathrm{CF}_{3}\left(\mathbf{1} \mathbf{a}-\mathbf{B P h}_{4}\right), \mathrm{Ph}\left(\mathbf{1 b}-\mathbf{B P h}_{4}\right), p-\mathrm{C}_{6} \mathrm{H}_{4} \mathrm{CH}_{3}(\mathbf{l} \mathbf{c}-$ $\left.\left.\mathbf{B P h}_{4}\right), p-\mathrm{C}_{6} \mathrm{H}_{4} \mathrm{Br}\left(\mathbf{1 d}-\mathbf{B P h}_{4}\right),{ }^{\mathrm{t}} \mathrm{Bu}\left(\mathbf{l e}-\mathrm{BPh}_{4}\right), \mathrm{H}\left(\mathbf{1 f}-\mathrm{BPh}_{4}\right)\right)$ have been protonated using an excess of $\mathrm{HBF}_{4} \cdot \mathrm{OEt}_{2}$ in $\mathrm{CD}_{2} \mathrm{Cl}_{2}$, furnishing the dicationic carbyne complexes $\left[\mathrm{Cp} * \mathrm{Ru} \equiv \mathrm{CCH}_{2} \mathrm{R}\left({ }^{\mathrm{i}} \mathrm{Pr}_{2} \mathrm{PNHPy}\right)\right]^{2+}\left(\mathrm{R}=p-\mathrm{C}_{6} \mathrm{H}_{4} \mathrm{CF}_{3}(\mathbf{2 a})\right.$,

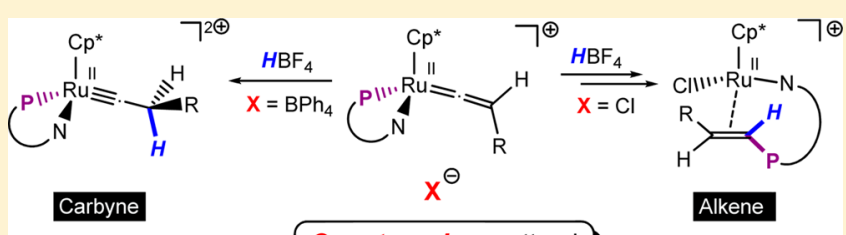

Counteranion matters! $\mathrm{Ph}$ (2b), $p-\mathrm{C}_{6} \mathrm{H}_{4} \mathrm{CH}_{3}$ (2c), $p-\mathrm{C}_{6} \mathrm{H}_{4} \mathrm{Br}$ (2d), ${ }^{\mathrm{B}} \mathrm{Bu}$ (2e), $\mathrm{H}$

(2f)), which were characterized in solution at low temperature by NMR spectroscopy. The corresponding reaction of the chloride salts $\mathbf{1 a}-\mathbf{C l}, \mathbf{1} \mathbf{b}-\mathbf{C l}, \mathbf{1} \mathbf{c}-\mathbf{C l}$, and $\mathbf{1 d}-\mathbf{C l}$ followed a different pathway, instead affording the novel alkene complexes $\left[\mathrm{Cp} * \mathrm{RuCl}\left(\kappa^{1}(N), \eta^{2}(C, C)-\mathrm{C}_{5} \mathrm{H}_{4} \mathrm{~N}-\mathrm{NHP}^{\mathrm{i}} \mathrm{Pr}_{2} \mathrm{CH}=\mathrm{CHR}\right)\right]\left[\mathrm{BF}_{4}\right](3 \mathrm{a}-\mathrm{d})$. In these species, the entering proton is located at the $\alpha-$ carbon atom of the former vinylidene ligand, which also forms a $\mathrm{P}-\mathrm{C}$ bond with the phosphorus atom of the ${ }^{\mathrm{i}} \mathrm{Pr}_{2} \mathrm{PNHPy} \mathrm{PNand}$ To shed light on the reaction mechanism, DFT calculations have been performed by considering several protonation sites. The computational results suggest metal protonation followed by insertion. The coordination of chloride to ruthenium leads to alkenyl species which can undergo a $\mathrm{P}-\mathrm{C}$ coupling to yield the corresponding alkene complexes. The noncoordinating nature of $\left[\mathrm{BPh}_{4}\right]^{-}$does not allow the stabilization of the unsaturated species coming from the insertion step, thus preventing this alternative pathway.
\end{abstract}

\section{INTRODUCTION}

Protonation of transition-metal vinylidene complexes is an established synthetic route for the preparation of cationic carbyne species. ${ }^{1}$ In most cases, the $\beta$-carbon atom of the vinylidene ligand is selectively protonated, furnishing carbyne complexes (Scheme 1), although there might be alternative protonation sites in the complex leading to other feasible reaction products. ${ }^{2}$

Scheme 1. Protonation of Transition-Metal Vinylidene Species at the $\beta$-Carbon

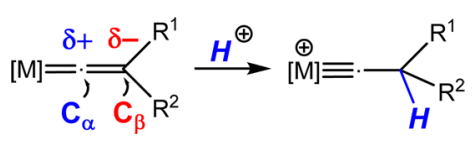

$\mathrm{Ru}$-carbyne complexes are scarce. ${ }^{3}$ At variance with this, Os-carbynes are well-known species ${ }^{1 \mathrm{~b}, 4}$ due to the remarkable preference of osmium (versus ruthenium) for higher oxidation states and formation of new metal-ligand bonds. ${ }^{5}$ Werner and co-workers reported the protonation of $[\mathrm{Ru}=\mathrm{C}=\mathrm{CHPh}(\mathrm{H})$ $\left.(\mathrm{Cl})\left(\mathrm{PCy}_{3}\right)_{2}\right]$ with acids $\mathrm{HX}$ having a noncoordinating anion $\mathrm{X}^{-}$in coordinating solvents $\mathrm{S}$ to yield the six-coordinate $\mathrm{Ru}-$ carbynes $\left[\mathrm{Ru} \equiv \mathrm{CCH}_{3}(\mathrm{H})(\mathrm{Cl})\left(\mathrm{PCy}_{3}\right)_{2}(\mathrm{~S})\right]^{+}\left(\mathrm{S}=\mathrm{Et}_{2} \mathrm{O}, \mathrm{H}_{2} \mathrm{O}\right.$, $\left.\mathrm{PhNMe}_{2}\right) .{ }^{6}$ In an analogous fashion, $[\mathrm{Ru}=\mathrm{C}=\mathrm{CHPh}-$ $\left.(\mathrm{Cl})_{2}\left(\mathrm{P}^{\mathrm{i}} \mathrm{Pr}_{3}\right)_{2}\right]$ and $\left[\mathrm{Ru}=\mathrm{C}=\mathrm{CHPh}\left(\mathrm{CF}_{3} \mathrm{COO}\right)(\mathrm{Cl})\left(\mathrm{P}^{\mathrm{i}} \mathrm{Pr}_{3}\right)_{2}\right]$ react with $\left[\mathrm{H}\left(\mathrm{OEt}_{2}\right)_{2}\right]\left[\mathrm{BAr}_{4}{ }_{4}\right]\left(\mathrm{Ar}^{\prime}=3,5\right.$-bis(trifluoromethyl)phenyl, $\left.\mathrm{C}_{6} \mathrm{H}_{4}\left(\mathrm{CF}_{3}\right)_{2}\right)$ acids, yielding the carbyne complexes $\left[\mathrm{Ru} \equiv \mathrm{CCH}_{2} \mathrm{Ph}(\mathrm{Cl})_{2}\left(\mathrm{PR}_{3}\right)_{2}\right]^{+}$and $\left[\mathrm{Ru} \equiv \mathrm{CCH}_{2} \mathrm{Ph}\left(\kappa^{2}(O, O)\right.\right.$ $\left.\left.\mathrm{CF}_{3} \mathrm{COO}\right)(\mathrm{Cl})\left(\mathrm{PR}_{3}\right)_{2}\right]^{+}$, respectively. ${ }^{7}$ The neutral vinylidene complexes $\left[\mathrm{Cp} * \mathrm{Ru}=\mathrm{C}=\mathrm{CHR}(\mathrm{Cl})\left(\mathrm{PPh}_{3}\right)\right]\left(\mathrm{R}={ }^{\mathrm{t}} \mathrm{Bu},{ }^{\mathrm{n}} \mathrm{Bu}, \mathrm{Ph}\right)$ react with $\mathrm{HBF}_{4} \cdot \mathrm{OEt}_{2}$ and $\mathrm{NaBAr}_{4}{ }_{4}$, furnishing cationic carbyne derivatives of the type $\left[\mathrm{Cp} * \mathrm{Ru} \equiv \mathrm{CCH}_{2} \mathrm{R}(\mathrm{Cl})\left(\mathrm{PPh}_{3}\right)\right]^{+}$. addition of electrophiles to the $\beta$-carbon of a $\mathrm{Ru}$-allenylidene complex has also been observed, leading to dicationic vinylcarbyne derivatives such as $[\mathrm{Cp} * \mathrm{Ru} \equiv \mathrm{CCH}=$ $\mathrm{CRR}^{\prime}($ dippe $\left.)\right]^{2+}\left(\mathrm{R}=\mathrm{H}, \mathrm{Ph} ; \mathrm{R}^{\prime}=\mathrm{Ph} ;\right.$ dippe $=1,2-$ bis(diisopropylphosphino)ethane $)^{9}$ and $\left[\mathrm{Cp}^{*} \mathrm{Ru} \equiv \mathrm{CCH}=\right.$ $\left.\mathrm{CRR}^{\prime}\left(\mathrm{PEt}_{3}\right)_{2}\right]^{2+}\left(\mathrm{R}=\mathrm{H}, \mathrm{Ph} ; \mathrm{R}^{\prime}=\mathrm{Ph}\right) .{ }^{10}$ Despite the fact that protonation usually takes place at the $\beta$-carbon of the vinylidene or allenylidene ligand, there are reports of apparent protonation at the $\alpha$-carbon. This is the case for the reaction of the nitrosyl vinylidene complex $\left[\mathrm{Ru}=\mathrm{C}=\mathrm{CHC}_{6} \mathrm{H}_{4} \mathrm{Me}(\mathrm{Cl})\right.$ -

Received: February 19, 2014

Published: May 5, 2014 
(NO) $\left.\left(\mathrm{PPh}_{3}\right)_{2}\right]$ with protic acids $\mathrm{HX}$, which leads to the $\mathrm{Ru}-$ alkenyl complexes $\left[\mathrm{RuCl}(\mathrm{X})\left\{(\mathrm{Z})-\mathrm{CH}=\mathrm{CHC}_{6} \mathrm{H}_{4} \mathrm{Me}\right)\right\}(\mathrm{NO})$ $\left.\left(\mathrm{PPh}_{3}\right)_{2}\right]\left(\mathrm{X}=\mathrm{Cl}, \mathrm{CF}_{3} \mathrm{COO}, \mathrm{FBF}_{3}\right) .{ }^{11} \mathrm{Ru}$-carbyne complexes are also accessible by synthetic methods other than protonation of vinylidenes. Thus, square-planar carbyne complexes of the type $\left[\mathrm{Ru} \equiv \mathrm{CR}\left(\mathrm{PCy}_{3}\right)_{2} \mathrm{X}\right]\left(\mathrm{X}=\mathrm{F}, \mathrm{Cl}, \mathrm{Br}, \mathrm{I}, \mathrm{CF}_{3} \mathrm{SO}_{3} ; \mathrm{R}={ }^{\mathrm{n}} \mathrm{Bu}\right.$, $\left.\mathrm{Ph}, p-\mathrm{C}_{6} \mathrm{H}_{4} \mathrm{CH}_{3}\right)$ have been prepared by net dehydrohalogenation of the Grubbs catalysts $\left[\mathrm{Ru}=\mathrm{CHR}\left(\mathrm{PCy}_{3}\right)_{2} \mathrm{Cl}_{2}\right]$ followed by substitution of the chloride ligand. ${ }^{12}$

In a recent work, we studied the alkyne to vinylidene rearrangement for the complexes $\left[\mathrm{Cp} * \mathrm{Ru}\left(\eta^{2}-\mathrm{HC} \equiv \mathrm{CR}\right)\right.$ $\left.\left({ }^{\mathrm{i}} \mathrm{Pr}_{2} \mathrm{PNHPy}\right)\right][\mathrm{X}]\left(\mathrm{R}=\mathrm{COOMe}, p-\mathrm{C}_{6} \mathrm{H}_{4} \mathrm{CF}_{3} ; \mathrm{X}=\mathrm{Cl}\right.$, $\left.\mathrm{BPh}_{4}\right){ }^{13}$ We found that the species having $\mathrm{Cl}^{-}$as a counteranion undergo faster isomerization to the corresponding vinylidene complexes $\left[\mathrm{Cp} * \mathrm{Ru}=\mathrm{C}=\mathrm{CHR}\left({ }^{\mathrm{i}} \mathrm{Pr}_{2} \mathrm{PNHPy}\right)\right]$ $[\mathrm{X}]$ in comparison to their counterparts with $\left[\mathrm{BPh}_{4}\right]^{-}$. The presence of $\mathrm{Cl}^{-}$or methanol $(\mathrm{MeOH})$ in solution with metastable $\pi$-alkyne complexes $\left[\mathrm{Cp} * \mathrm{Ru}\left(\eta^{2}-\mathrm{HC} \equiv \mathrm{CR}\right)\right.$ $\left.\left({ }^{\mathrm{i}} \mathrm{Pr}_{2} \mathrm{PNHPy}\right)\right]\left[\mathrm{BPh}_{4}\right]$ causes an increase in the rate of isomerization to vinylidene. According to DFT calculations, a $\mathrm{Cl}^{-}$or $\mathrm{MeOH}$-assisted hydrogen migration mechanism involving an acidic hydrido-alkynyl intermediate was envisaged. ${ }^{13}$ In the same way that the presence of $\mathrm{Cl}^{-}$or $\left[\mathrm{BPh}_{4}\right]^{-}$ has a strong effect on the alkyne to vinylidene isomerization rates, we have now found that the products of the protonation of the vinylidene complexes $[\mathrm{Cp} * \mathrm{Ru}=\mathrm{C}=\mathrm{CHR}$ $\left.\left({ }^{\mathrm{i}} \mathrm{Pr}_{2} \mathrm{PNHPy}\right)\right]^{+}\left(\mathrm{R}=p-\mathrm{C}_{6} \mathrm{H}_{4} \mathrm{CF}_{3}, \mathrm{Ph}, p-\mathrm{C}_{6} \mathrm{H}_{4} \mathrm{CH}_{3}, p-\mathrm{C}_{6} \mathrm{H}_{4} \mathrm{Br}\right.$, $\left.{ }^{t} \mathrm{Bu}, \mathrm{H}\right)$ also depend on the nature of the counteranion. Thus, in the presence of the poorly coordinating $\left[\mathrm{BPh}_{4}\right]^{-}$counteranion, the protonation of vinylidene complexes with an excess of $\mathrm{HBF}_{4} \cdot \mathrm{OEt}_{2}$ leads to the corresponding dicationic carbyne derivatives. However, with chloride as counteranion, an unusual reaction takes place, furnishing the novel alkene complexes $\left[\mathrm{Cp} * \mathrm{RuCl}\left(\kappa^{1}(\mathrm{~N}), \eta^{2}(\mathrm{C}, \mathrm{C})-\mathrm{C}_{5} \mathrm{H}_{4} \mathrm{NNHP}^{\mathrm{i}} \mathrm{Pr}_{2} \mathrm{CH}=\mathrm{CHR}\right)\right]^{+}(\mathrm{R}=$ $\left.p-\mathrm{C}_{6} \mathrm{H}_{4} \mathrm{CF}_{3}, \mathrm{Ph}, p-\mathrm{C}_{6} \mathrm{H}_{4} \mathrm{CH}_{3}, p-\mathrm{C}_{6} \mathrm{H}_{4} \mathrm{Br}\right)$. These species locate the initial proton at the $\alpha$-carbon atom and exhibit a new bond between the phosphine ligand and the former vinyl fragment. We have performed DFT calculations in order to clarify the mechanistic details for these protonation reactions and to rationalize the role played by the different counteranions. The experimental and theoretical details are presented and discussed in this study.

\section{RESULTS AND DISCUSSION}

Experimental Study. Protonation of Vinylidene Complexes in the Presence of $\left[\mathrm{BPh}_{4}\right]^{-}$as Counteranion. The vinylidene complexes $\left[\mathrm{Cp} * \mathrm{Ru}=\mathrm{C}=\mathrm{CHR}\left({ }^{\mathrm{i}} \operatorname{Pr}_{2} \mathrm{PNHPy}\right)\right][\mathrm{Cl}]$ $\left(\mathrm{R}=p-\mathrm{C}_{6} \mathrm{H}_{4} \mathrm{CF}_{3}(\mathbf{1} \mathrm{a}-\mathrm{Cl}),{ }^{,} \mathrm{Ph}(\mathbf{1} \mathbf{b}-\mathbf{C l}), p-\mathrm{C}_{6} \mathrm{H}_{4} \mathrm{CH}_{3}(\mathbf{1} \mathbf{c}-\mathrm{Cl})\right.$, $\left.p-\mathrm{C}_{6} \mathrm{H}_{4} \mathrm{Br}(\mathbf{1} \mathbf{d}-\mathbf{C l}),{ }^{\mathrm{t}} \mathrm{Bu}(\mathbf{1 e}-\mathbf{C l})\right)$ are generated by direct reaction of the corresponding 1-alkynes with the chloro complex $\left[\mathrm{Cp} * \mathrm{RuCl}\left({ }^{\mathrm{i}} \mathrm{Pr}_{2} \mathrm{PNHPy}\right)\right]$ in dichloromethane at room temperature. These vinylidene derivatives are readily converted into their $\left[\mathrm{BPh}_{4}\right]^{-}$salts $[\mathrm{Cp} * \mathrm{Ru}=\mathrm{C}=\mathrm{CHR}$ $\left.\left({ }^{\mathrm{i}} \mathrm{Pr}_{2} \mathrm{PNHPy}\right)\right]\left[\mathrm{BPh}_{4}\right]\left(\mathrm{R}=p-\mathrm{C}_{6} \mathrm{H}_{4} \mathrm{CF}_{3}\left(\mathbf{l a}-\mathbf{B P h}_{4}\right),{ }^{13} \mathrm{Ph}(\mathbf{1 b}-\right.$ $\mathbf{B P h}_{4}$ ), $p-\mathrm{C}_{6} \mathrm{H}_{4} \mathrm{CH}_{3}\left(\mathbf{c}-\mathbf{B P h}_{4}\right), p-\mathrm{C}_{6} \mathrm{H}_{4} \mathrm{Br}\left(\mathbf{1 d}-\mathbf{B P h}_{4}\right),{ }^{t} \mathrm{Bu}(\mathbf{l e}-$ $\left.\mathbf{B P h}_{4}\right)$ ) by metathetical exchange of chloride with $\mathrm{NaBPh}_{4}$ in $\mathrm{MeOH}$. In an analogous fashion, the primary vinylidene complex $\left[\mathrm{Cp} * \mathrm{Ru}=\mathrm{C}=\mathrm{CH}_{2}\left({ }^{\mathrm{i}} \mathrm{Pr}_{2} \mathrm{PNHPy}\right)\right][\mathrm{Cl}](\mathbf{1 f}-\mathrm{Cl})$ was prepared by the reaction of $\left[\mathrm{Cp} * \operatorname{RuCl}\left({ }^{\mathrm{i}} \mathrm{Pr}_{2} \mathrm{PNHPy}\right)\right]$ with $\mathrm{HC} \equiv \mathrm{CSiMe}_{3}$ and then transformed into $[\mathrm{Cp} * \mathrm{Ru}=\mathrm{C}=$ $\left.\mathrm{CHR}\left({ }^{\mathrm{i}} \mathrm{Pr}_{2} \mathrm{PNHPy}\right)\right]\left[\mathrm{BPh}_{4}\right]\left(\mathbf{1} \mathbf{f}-\mathbf{B P h}_{4}\right)$ by reaction with $\mathrm{NaBPh}_{4}$ in $\mathrm{MeOH}$. The NMR spectra of all the new vinylidene derivatives, in the form of either $\mathrm{Cl}^{-}$or $\left[\mathrm{BPh}_{4}\right]^{-}$salts, are consistent with those reported for $\mathbf{1 a}-\mathbf{C l} / \mathbf{B P h}_{4}$ and for $\left[\mathrm{Cp} * \mathrm{Ru}=\mathrm{C}=\mathrm{CHCOOMe}\left({ }^{\mathrm{i}} \operatorname{Pr}_{2} \mathrm{PNHPy}\right)\right][\mathrm{X}](\mathrm{X}=\mathrm{Cl}$, $\left.\mathrm{BPh}_{4}\right) .{ }^{13}$ The most relevant feature of the ${ }^{1} \mathrm{H}$ NMR spectra of these compounds is the large difference of ca. $5 \mathrm{ppm}$ in the chemical shift observed for the $\mathrm{NH}$ proton on comparison of the $\mathrm{Cl}^{-}$salts with their $\left[\mathrm{BPh}_{4}\right]^{-}$homologues. This difference in chemical shifts has been attributed to the formation of a strong hydrogen bond between the chloride counteranion and the $\mathrm{NH}$ proton in the case of complexes $\mathbf{1 a - C l - 1 f - C l}{ }^{13}$ Such an interaction causes a deshielding effect in the $\mathrm{NH}$ proton, which appears above $10 \mathrm{ppm}$ in the ${ }^{1} \mathrm{H}$ NMR spectra, whereas for $\left[\mathrm{BPh}_{4}\right]^{-}$salts the observed chemical shift range is 5-6 ppm.

The vinylidene complexes $\mathbf{1 a}-\mathbf{f}$ having $\left[\mathrm{BPh}_{4}\right]^{-}$as counteranion react with an excess of $\mathrm{HBF}_{4} \cdot \mathrm{OEt}_{2}$ at $-80{ }^{\circ} \mathrm{C}$ in $\mathrm{CD}_{2} \mathrm{Cl}_{2}$, furnishing the dicationic carbyne derivatives $[\mathrm{Cp} * \mathrm{Ru} \equiv$ $\left.\mathrm{CCH}_{2} \mathrm{R}\left({ }^{\mathrm{i}} \mathrm{Pr}_{2} \mathrm{PNHPy}\right)\right]\left[\mathrm{BF}_{4}\right]_{2}\left(\mathrm{R}=p-\mathrm{C}_{6} \mathrm{H}_{4} \mathrm{CF}_{3}(\mathbf{2 a}), \mathrm{Ph}(\mathbf{2 b})\right.$, $p-\mathrm{C}_{6} \mathrm{H}_{4} \mathrm{CH}_{3}$ (2c), $p-\mathrm{C}_{6} \mathrm{H}_{4} \mathrm{Br}(\mathbf{2 d}),{ }^{\mathrm{t}} \mathrm{Bu}(\mathbf{2 e}), \mathrm{H}(\mathbf{2 f})$ ) (Scheme 2).

Scheme 2. Protonation of Vinylidene Species $1 \mathrm{a}-\mathrm{BPh}_{4}-1 \mathrm{f}-$ $\mathrm{BPh}_{4}$
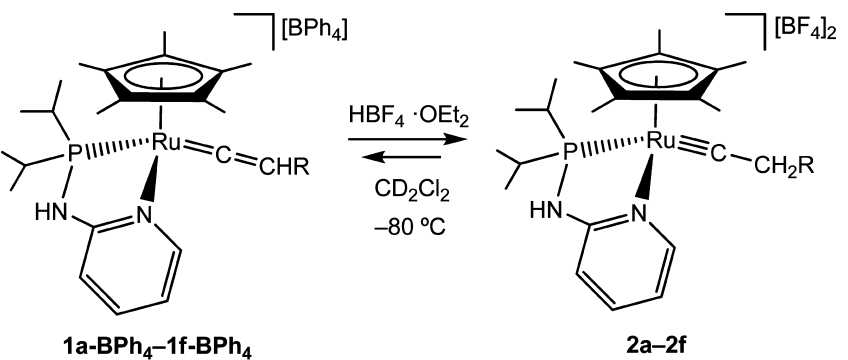

$\mathrm{R}=p-\mathrm{C}_{6} \mathrm{H}_{4} \mathrm{CF}_{3}(\mathbf{a}), \mathrm{C}_{6} \mathrm{H}_{5}(\mathbf{b}), p-\mathrm{C}_{6} \mathrm{H}_{4} \mathrm{CH}_{3}(\mathbf{c}), p-\mathrm{C}_{6} \mathrm{H}_{4} \mathrm{Br}(\mathbf{d}),{ }^{\mathrm{t}} \mathrm{Bu}(\mathbf{e}), \mathrm{H}(\mathbf{f})$

These carbyne complexes $\mathbf{2 a}-\mathbf{f}$ are stable in solution below 0 ${ }^{\circ} \mathrm{C}$. Above this temperature they decompose, yielding mixtures of uncharacterized species. For this reason, they were not isolated but were characterized in $\mathrm{CD}_{2} \mathrm{Cl}_{2}$ solution by $\mathrm{NMR}$ experiments at low temperature. An excess of $\mathrm{HBF}_{4} \cdot \mathrm{OEt}_{2}$ is mandatory in order to shift the protonation equilibrium toward the dicationic carbyne species. Otherwise, mixtures of vinylidene and carbyne complexes are observed. The ${ }^{1} \mathrm{H}$ NMR spectra of the carbyne complexes $2 \mathbf{a}-\mathbf{e}$ show two characteristic doublets (intensity of one proton each) with a large ${ }^{2} J(H, H)$ coupling constant of ca. $21 \mathrm{~Hz}$. These signals correspond to the $\mathrm{AB}$ spin system formed by the two diastereotopic hydrogen atoms attached to the $\beta$-carbon of the carbyne ligand. This pattern has also been observed for the monocationic carbyne derivatives $\left[\mathrm{Cp} * \mathrm{Ru} \equiv \mathrm{CCH}_{2} \mathrm{R}\left(\mathrm{PPh}_{3}\right) \mathrm{Cl}\right]^{+}\left(\mathrm{R}={ }^{\mathrm{t}} \mathrm{Bu},{ }^{\mathrm{n}} \mathrm{Bu}, \mathrm{Ph}\right){ }^{8}$ In the case of the carbyne complex $2 \mathrm{f}$, these resonances are absent, given the fact that the protonation of the primary vinylidene complex $\mathbf{1 f}-\mathbf{B P h}_{4}$ leads to the methyl carbyne derivative $\left[\mathrm{Cp} * \mathrm{Ru} \equiv \mathrm{CCH}_{3}\left({ }^{\mathrm{i}} \mathrm{Pr}_{2} \mathrm{PNHPy}\right)\right]\left[\mathrm{BF}_{4}\right]_{2}$. Instead, one singlet at $3.02 \mathrm{ppm}$ with intensity corresponding to three protons is observed for the methyl group. This resonance is correlated with one singlet at $45.1 \mathrm{ppm}$ in the ${ }^{13} \mathrm{C}\left\{{ }^{1} \mathrm{H}\right\} \mathrm{NMR}$ spectrum. For $2 \mathrm{a}-\mathbf{e}, 2 \mathrm{D}{ }^{1} \mathrm{H}-{ }^{13} \mathrm{C}$ gHSQCAD NMR experiments show correlation of the two doublets for the $\mathrm{CH}_{2} \mathrm{R}$ group with one secondary carbon atom, which appears in the range 61-70 ppm depending on the $R$ substituent. The resonance of the $\alpha$-carbon atom of the carbyne ligand is present as one doublet between 348 and 364 ppm, with coupling constants ${ }^{2} J(\mathrm{P}, \mathrm{C})$ of $11-14 \mathrm{~Hz}$. For all of the carbyne 
compounds, the ${ }^{31} \mathrm{P}\left\{{ }^{1} \mathrm{H}\right\}$ NMR spectra consist of one sharp singlet which shows very little shift with respect to the resonance of the parent vinylidene derivative. The NMR spectroscopic data reveal the clean formation of dicationic carbyne complexes as products of the reaction of the monocationic vinylidene complexes $\mathbf{1 a}-\mathbf{B P h}_{\mathbf{4}}-\mathbf{1 f}-\mathbf{B P h} \mathbf{P h}_{4}$ with an excess of $\mathrm{HBF}_{4}$ at low temperature. However, as the temperature increases, the carbyne complexes decompose in solution. All attempts to isolate any of them in solid form were unsuccessful. In previous studies, we had observed the formation of dicationic alkenyl-carbyne species of the type $\left[\mathrm{Cp} * \mathrm{Ru} \equiv \mathrm{CCH}=\mathrm{CRR}^{\prime}(\mathrm{P})_{2}\right]\left[\mathrm{BAr}_{4}\right]_{2}\left(\mathrm{RR}^{\prime}=\mathrm{HPh}, \mathrm{Ph}_{2} ;(\mathrm{P})_{2}\right.$ $=$ dippe, $\left.\left.\left(\mathrm{PEt}_{3}\right)_{2}\right)\right)^{9,10}$ These species trigger the keto-enol tautomerism in ketones and display an interesting reactivity toward organic molecules with acidic hydrogen atoms. ${ }^{10,14} \mathrm{At}$ variance with the complexes $\mathbf{2 a}-\mathbf{f}$, the dicationic alkenylcarbyne species $\left[\mathrm{Cp} * \mathrm{Ru} \equiv \mathrm{CCH}=\mathrm{CRR}^{\prime}(\mathrm{P})_{2}\right]\left[\mathrm{BAr}_{4}{ }_{4}\right]_{2}$ are stable at room temperature and were subjected to $\mathrm{X}$-ray structure analysis.

Protonation of Vinylidene Complexes in the Presence of $\mathrm{Cl}^{-}$as Counteranion. The course of the protonation of the vinylidene ligand in complexes $\mathbf{1 a}-\mathbf{C l}-\mathbf{1 d}-\mathbf{C l}$, which present chloride as a counteranion, is different from the case of complexes $\mathbf{1 a}-\mathbf{B P h}_{\mathbf{4}}-\mathbf{1 f}-\mathbf{B P h}_{\mathbf{4}}$. That is, the protonation of $\mathbf{1 a}$ Cl-1d-Cl with a slight excess over the stoichiometric amount of $\mathrm{HBF}_{4} \cdot \mathrm{OEt}_{2}$ at $-80{ }^{\circ} \mathrm{C}$ in dichloromethane followed by warming to room temperature yielded a red-brown solution, from which red-brown or orange-brown solids were isolated in moderate yields. The ${ }^{31} \mathrm{P}\left\{{ }^{1} \mathrm{H}\right\}$ NMR spectra of these complexes display one sharp singlet between 55 and $58 \mathrm{ppm}$. These resonances are considerably shifted (ca. $80 \mathrm{ppm}$ ) to upper field with respect to the signals for the parent vinylidene complexes or those attributable to carbyne complexes. Furthermore, this large shift seems consistent with a decoordination of the phosphorus atom from the ruthenium. The ${ }^{1} \mathrm{H}$ NMR spectra of these complexes display two doublets of doublets between 4 and $6 \mathrm{ppm}$. These doublets show correlation with each other in the $2 \mathrm{D}{ }^{1} \mathrm{H}-{ }^{1} \mathrm{H}$ COSY NMR spectra. The observed coupling constants of $12 \mathrm{~Hz}$ are considered ${ }^{3} \mathrm{~J}(\mathrm{H}, \mathrm{H})$ couplings. The other coupling constants, with values ranging from 8.6 to 16 $\mathrm{Hz}$, are attributed to couplings to ${ }^{31} \mathrm{P}$ nuclei. This is in line with the correlations observed in the $2 \mathrm{D}{ }^{1} \mathrm{H}-{ }^{13} \mathrm{C}$ gHSQCAD NMR spectra. Each doublet of doublets correlates with one doublet signal in the corresponding ${ }^{13} \mathrm{C}\left\{{ }^{1} \mathrm{H}\right\}$ NMR spectra, one at ca. $32 \mathrm{ppm}$ and the other between 65 and $69 \mathrm{ppm}$. The coupling constants of $80 \mathrm{~Hz}$ for the doublet resonance near $32 \mathrm{ppm}$ indicate a phosphorus-carbon coupling through one bond, ${ }^{1} J(C, P)$. The coupling constant for the other resonance is much smaller, $6 \mathrm{~Hz}$, and is consistent with a coupling through two bonds, ${ }^{2} J(\mathrm{C}, \mathrm{P})$. These spectroscopic data are interpreted in terms of the formation of a new ligand in which the proton is located at the $\alpha$-carbon and a new $\mathrm{P}-\mathrm{C}$ bond has been created between the phosphorus atom and the $\alpha$-carbon of the former vinylidene ligand. The result is a $\eta^{2}$-alkene complex containing a quaternary phosphorus atom attached to the coordinated olefin and to the NH group, with the pyridyl group still bound to ruthenium. These products $\mathbf{3} \mathbf{a}-\mathbf{d}$ formally contain $\mathrm{Ru}(\mathrm{II})$, and one chloride ligand is needed in order to fill one vacant coordination site (Scheme 3). No attack of the pyridyl group on the $\alpha$-carbon has been observed during the course of this reaction. $^{15}$

Hence, the protonation of complexes $\mathbf{1 a}-\mathbf{C l}-\mathbf{1 d}-\mathbf{C l}$ leads to the novel species $\left[\mathrm{Cp} * \mathrm{RuCl}\left(\kappa^{1}(N), \eta^{2}(C, C)-\mathrm{C}_{5} \mathrm{H}_{4} \mathrm{~N}\right.\right.$ -

Scheme 3. Protonation of Vinylidene Species $1 \mathrm{a}-\mathrm{Cl}-\mathbf{1 d}-\mathrm{Cl}$

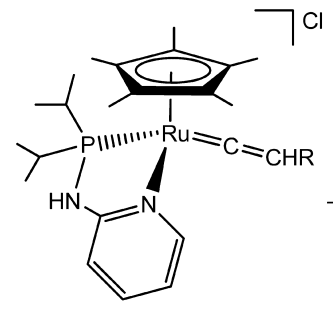

1a-Cl-1d-Cl

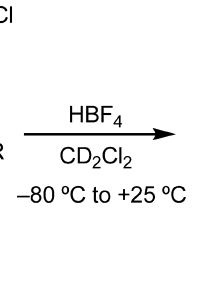

$p-\mathrm{C}_{6} \mathrm{H}_{4} \mathrm{CF}_{3}(\mathbf{a})$

$\left.\left.\mathrm{NHP}^{\mathrm{i}} \mathrm{Pr}_{2} \mathrm{CH}=\mathrm{CHR}\right)\right]\left[\mathrm{BF}_{4}\right]\left(\mathrm{R}=p-\mathrm{C}_{6} \mathrm{H}_{4} \mathrm{CF}_{3}(3 \mathbf{a}), \mathrm{Ph}(3 \mathbf{b})\right.$ $p-\mathrm{C}_{6} \mathrm{H}_{4} \mathrm{CH}_{3}$ (3c), $\left.p-\mathrm{C}_{6} \mathrm{H}_{4} \mathrm{Br}(3 \mathrm{~d})\right)$ instead of the expected carbyne derivatives. The protonation of the vinylidene complexes $\mathbf{1 e - C l}$ and $\mathbf{1 f}-\mathbf{C l}$ did not yield any characterizable compounds. However, the monitoring of the protonation reactions of these vinylidene derivatives by ${ }^{31} \mathrm{P}\left\{{ }^{1} \mathrm{H}\right\}$ NMR suggests that the phosphorus atom remains attached to ruthenium, since no signals attributable to uncoordinated phosphorus (i.e., in the range 55-60 ppm) were observed in the reaction mixtures. At variance with the corresponding carbyne complexes, the derivatives $\mathbf{3 a}-\mathbf{d}$ are stable species at room temperature and amenable to isolation. Recrystallization of 3d from dichloromethane/petroleum ether afforded single crystals suitable for X-ray structure analysis. An ORTEP view of the complex $\left[\mathrm{Cp}^{*} \mathrm{RuCl}\left(\kappa^{1}(N), \eta^{2}(C, C)-\mathrm{C}_{5} \mathrm{H}_{4} \mathrm{~N}-\mathrm{NHP} \mathrm{Pr}_{2} \mathrm{CH}=\right.\right.$ $\left.\left.\mathrm{CHC}_{6} \mathrm{H}_{4} \mathrm{Br}\right)\right]^{+}$is shown in Figure 1 , together with the most relevant bond distances and angles.

The structure of $\mathbf{3 d}$ contains one disordered molecule of adventitious water of crystallization. The cation $[\mathrm{Cp} * \mathrm{RuCl}-$

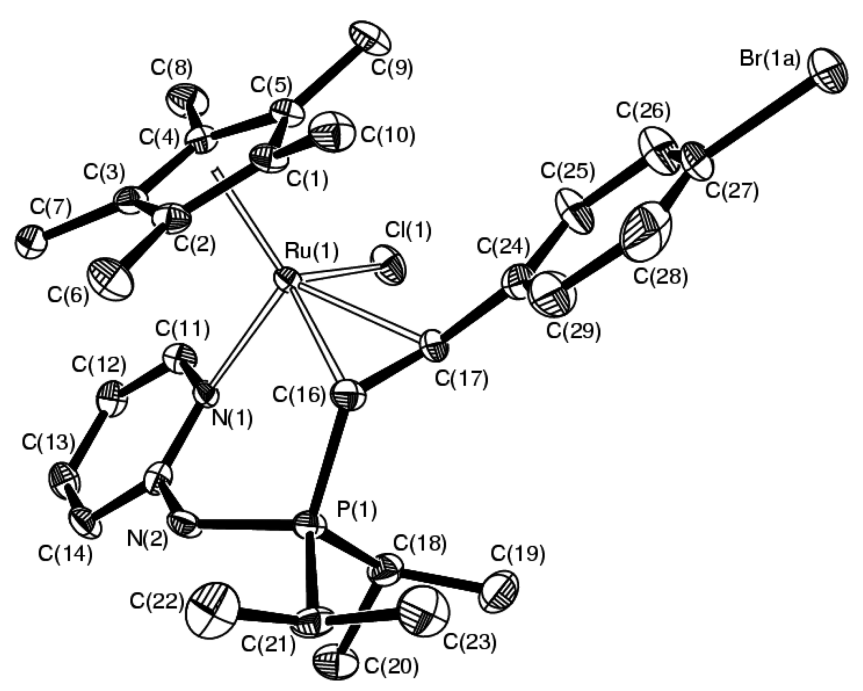

Figure 1. ORTEP drawing (50\% displacement ellipsoids, hydrogen atoms omitted) of $\left[\mathrm{Cp} * \mathrm{RuCl}\left(\kappa^{1}(N), \eta^{2}(C, C)-\mathrm{C}_{5} \mathrm{H}_{4} \mathrm{NNHP}^{\mathrm{i}} \mathrm{Pr}_{2} \mathrm{CH}=\right.\right.$ $\left.\left.\mathrm{CHC}_{6} \mathrm{H}_{4} \mathrm{Br}\right)\right]^{+}$in $3 \mathrm{~d}$. Selected bond lengths $(\AA)$ and angles (deg) with estimated standard deviations in parentheses: $\mathrm{Ru}(1)-\mathrm{Cl}(1)$ 2.4553(11), $\mathrm{Ru}(1)-\mathrm{N}(1)$ 2.186(3), $\mathrm{Ru}(1)-\mathrm{C}(1) 2.187(4), \mathrm{Ru}(1)-$ $\mathrm{C}(2)$ 2.194(4), $\mathrm{Ru}(1)-\mathrm{C}(3)$ 2.278(4), $\mathrm{Ru}(1)-\mathrm{C}(4)$ 2.236(4), $\mathrm{Ru}(1)-\mathrm{C}(5)$ 2.167(4), $\mathrm{Ru}(1)-\mathrm{C}(16) 2.150(4), \quad \mathrm{Ru}(1)-\mathrm{C}(17)$ 2.171(4), $\mathrm{P}(1)-\mathrm{C}(16) 1.760(4), \mathrm{C}(16)-\mathrm{C}(17) 1.417(6) ; \mathrm{Cl}(1)-$ $\mathrm{Ru}(1)-\mathrm{N}(1)$ 85.24(9), $\mathrm{Cl}(1)-\mathrm{Ru}(1)-\mathrm{C}(16)$ 113.74(12), $\mathrm{Cl}(1)-$ $\mathrm{Ru}(1)-\mathrm{C}(17)$ 80.93(12), N(1)-Ru(1)-C(16) 92.68(13), N(1)$\mathrm{Ru}(1)-\mathrm{C}(17)$ 109.88(14), C(16) $-\mathrm{Ru}(1)-\mathrm{C}(17) 38.28(16), \mathrm{P}(1)-$ $\mathrm{C}(16)-\mathrm{C}(17) 121.6(3)$. 
$\left.\left(\kappa^{1}(N), \eta^{2}(C, C)-\mathrm{C}_{5} \mathrm{H}_{4} \mathrm{NNHP} \mathrm{Pr}_{2} \mathrm{CH}=\mathrm{CHC}_{6} \mathrm{H}_{4} \mathrm{Br}\right)\right]^{+}$in $\mathbf{3 d}$ has a three-legged piano-stool structure, with the ruthenium atom bound to one nitrogen atom of the pyridyl group, one chloride, and the $\mathrm{C}=\mathrm{C}$ double bond. The ruthenium atom has a formal oxidation state of II, with the four-coordinate phosphorus atom bearing a +1 charge in a phosphonium moiety. The $C(16)-$ $\mathrm{C}(17)$ bond distance is consistent with a slightly weakened double bond, similar to that observed in other ruthenium $\pi$ alkene complexes. ${ }^{16,17}$ The $\mathrm{Ru}(1)-\mathrm{C}(16)$ and $\mathrm{Ru}(1)-\mathrm{C}(17)$ separations are slightly different from each other $(0.021(4) \AA)$, indicative of some nonsymmetric interaction between the ruthenium and the olefin. The phosphorus atom and the $p$ bromophenyl substituent are arranged with $E$ stereochemistry across the double bond. The value of $12 \mathrm{~Hz}$ measured for the vicinal coupling constant ${ }^{3} \mathrm{~J}(\mathrm{H}, \mathrm{H})$ of the protons on the double bond is consistent with the stereochemistry found by $\mathrm{X}$-ray crystallography. The bond lengths $\mathrm{Ru}(1)-\mathrm{N}(1)$ and $\mathrm{Ru}(1)-$ $\mathrm{Cl}(1)$ are very similar to those found in the parent complex $\left[\mathrm{Cp} * \mathrm{RuCl}\left({ }^{\mathrm{i}} \operatorname{Pr}_{2} \mathrm{PNHPy}\right)\right]{ }^{18}$ whereas the $\mathrm{P}(1)-\mathrm{C}(16)$ separation of $1.760(4) \AA$ is of the same order as the $\mathrm{P}-\mathrm{C}$ bond distance found in the vinyl-phosphonio complex [Cp*Ru$\left.\left(\mathrm{PPh}_{3}\right)\left(\mathrm{C}_{6} \mathrm{H}_{4} \mathrm{PPh}_{2} \mathrm{CH}=\mathrm{CH}_{2}\right)\right]\left[\mathrm{PF}_{6}\right](1.777(9) \AA) .{ }^{17}$

It is clear that the present counteranion plays an important role in determining the ultimate products of the protonation reaction of these vinylidene complexes. In this sense, our results are remarkable not only because they demonstrate the existence of alternative reaction pathways but also because of the unusual nature of the product resulting from the protonation of the vinylidene complexes with chloride as counteranion. The formation of complexes $3 \mathbf{a}-\mathbf{d}$ might initially suggest that protonation seemingly takes place on the $\alpha$-carbon of the vinylidene ligand. However, this carbon atom is traditionally considered as electrophilic and usually tends to undergo several kinds of nucleophilic additions. ${ }^{19}$

In order to follow the trail of this alternative protonation, we have monitored by $\mathrm{VT}-{ }^{31} \mathrm{P}\left\{{ }^{1} \mathrm{H}\right\}$ NMR spectroscopy the reaction of $1 \mathrm{a}-\mathrm{Cl}$ with $\mathrm{HBF}_{4} \cdot \mathrm{OEt}_{2}$ in the complex to acid ratio $1: 1$ in $\mathrm{CD}_{2} \mathrm{Cl}_{2}$ in the temperature range of -80 to $+25^{\circ} \mathrm{C}$ (Figure 2). At $-80^{\circ} \mathrm{C}$ the NMR spectrum basically consists of one rather broad resonance at $136.1 \mathrm{ppm}$, which is attributed to the vinylidene complex $\mathbf{1 a - C l}$. There is a minor peak at 133.8 ppm which might be attributed to a small amount of the carbyne complex 2a. As temperature is raised, two resonances at 128.9 and $140 \mathrm{ppm}$ increase their intensities at the expense of the signal at $136.1 \mathrm{ppm}$. At $0{ }^{\circ} \mathrm{C}$, the signal at $136.1 \mathrm{ppm}$ disappears almost completely, and two new resonances are observed at 56.6 and $56.9 \mathrm{ppm}$. These new signals correspond to species in which the $\mathrm{Ru}-\mathrm{P}$ bond has been cleaved, being replaced by a new $\mathrm{P}-\mathrm{C}$ bond. At $+25^{\circ} \mathrm{C}$, only the peak at 56.7 $\mathrm{ppm}$ corresponding to the final product $3 \mathrm{a}$ is observed. This experiment shows that at least another species in which no direct $\mathrm{Ru}-\mathrm{P}$ bond is present can be detected. Likewise, the resonances at 128.9 and $140 \mathrm{ppm}$ correspond to intermediates of unknown structure, but in which the $\mathrm{Ru}-\mathrm{P}$ is preserved.

In the course of this reaction, the variation of the ${ }^{1} \mathrm{H}$ and ${ }^{19} \mathrm{~F}$ NMR spectra with respect to the temperature was also monitored. The variation of the ${ }^{19} \mathrm{~F}$ NMR spectrum with temperature parallels that previously observed for ${ }^{31} \mathrm{P}\left\{{ }^{1} \mathrm{H}\right\}$ NMR experiments. At $-80{ }^{\circ} \mathrm{C}$ the ${ }^{19} \mathrm{~F}$ NMR spectrum shows one resonance at $-62.5 \mathrm{ppm}$, which is again attributed to the vinylidene complex 1a-Cl. As temperature is raised, two new peaks at -62.9 and $-63.4 \mathrm{ppm}$ increase their intensities at the expense of the signal at $-62.5 \mathrm{ppm}$. At $0{ }^{\circ} \mathrm{C}$, two new signals

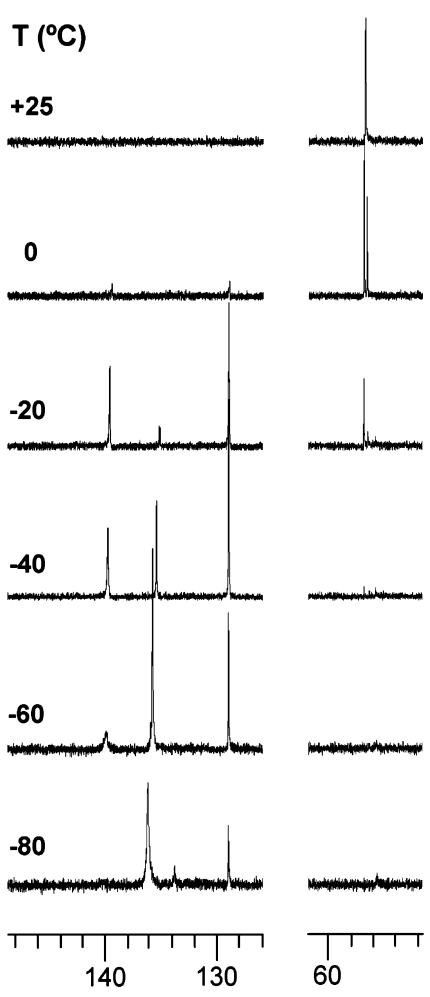

Figure 2. VT ${ }^{31} \mathrm{P}\left\{{ }^{1} \mathrm{H}\right\}$ NMR $(202.31 \mathrm{MHz})$ of a sample made up by addition of 1 equiv of $\mathrm{HBF}_{4} \cdot \mathrm{OEt}_{2}$ to a frozen $\mathrm{CD}_{2} \mathrm{Cl}_{2}$ solution of $1 \mathrm{a}$ $\mathrm{Cl}$, followed by subsequent warming to the indicated temperatures.

are observed at -63.0 and $-63.1 \mathrm{ppm}$, whereas at $+25^{\circ} \mathrm{C}$, only the resonance corresponding to the final product $3 \mathbf{a}$ is observed $(-63.2 \mathrm{ppm})$. The ${ }^{1} \mathrm{H}$ NMR spectra were rather complex due to the overlapping of signals for several species, as well as to the presence of resonances due to the diethyl ether of the $\mathrm{HBF}_{4}$. $\mathrm{OEt}_{2}$ used in the protonation. In the studied range of temperatures, no signals attributable to hydride ligands were observed on the high-field region of the ${ }^{1} \mathrm{H}$ NMR spectra. Between -20 and $0{ }^{\circ} \mathrm{C}$, two doublets of doublets appear at 3.40 and $5.30 \mathrm{ppm}$. These signals are due to the $\mathrm{CH}$ protons of the intermediate species containing a $\eta^{2}$-alkene ligand. At $+25{ }^{\circ} \mathrm{C}$ these signals disappear, being replaced by one set of doublet of doublets corresponding to the final product $3 \mathrm{a}$. There is no ${ }^{1} \mathrm{H}$ NMR evidence for the formation of the carbyne complex $2 a$ in the course of the protonation of $\mathbf{1 a}-\mathbf{C l}$. Given the importance of chloride, we also studied the protonation reactions using anhydrous $\mathrm{HCl}$ (generated by reaction of $\mathrm{Me}_{3} \mathrm{SiCl}$ with $\mathrm{MeOH}$ in $\mathrm{Et}_{2} \mathrm{O}$ ) as acid. The reaction of $\mathbf{1 a}-\mathbf{C l}$ with $\mathrm{HCl}$ follows the same course as that using $\mathrm{HBF}_{4} \cdot \mathrm{OEt}_{2}$. However, no reaction is observed between $\mathbf{1 a}-\mathbf{B P h}_{4}$ and $\mathrm{HCl}$ under similar conditions. The VT ${ }^{31} \mathrm{P}\left\{{ }^{1} \mathrm{H}\right\}$ NMR spectra show the resonance corresponding to the starting vinylidene complex unchanged. At $+25^{\circ} \mathrm{C}$ the signal collapses and the NMR spectrum becomes featureless. This is due to the formation of a very insoluble orange precipitate in the NMR tube. No attempts were made to isolate or characterize the product resulting from the protonation of $\mathbf{1 a}-\mathbf{B P h}_{4}$ with $\mathrm{HCl}$, but it became clear that the carbyne complex $2 \mathrm{a}$ is not formed under these conditions.

Computational Study. In order to obtain mechanistic insights into the formation of the alkene complexes $3 a-d, D F T$ studies have been performed on the protonation of complex 1a$\mathrm{Cl}$ by $\mathrm{HBF}_{4} \cdot \mathrm{OEt}_{2}$ in dichloromethane (DCM). All intermediates and transition states were optimized in the gas phase, and 
the energies were corrected using a continuum description for the solvent (see Computational Details). From this point onward, all energies reported correspond with Gibbs energies in dichloromethane in $\mathrm{kcal} \mathrm{mol}^{-1}$. Suffix a addresses the substrate $\left(\mathrm{R}=p-\mathrm{C}_{6} \mathrm{H}_{4} \mathrm{CF}_{4}\right)$, and suffixes $\mathbf{c}$ and $\mathbf{t}$ indicate the cis or trans stereochemistry of both alkenyl and alkene moieties.

Protonation Step. The first step of the mechanism deals with the protonation of $\mathrm{Ru}$-vinylidene reactants. This process can occur at several locations, and the most plausible protonation sites are collected in Scheme 4. The entering

Scheme 4. Protonation Sites Considered in the Computational Study

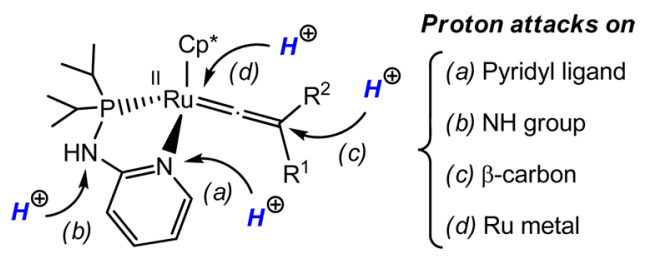

proton (in boldface italics) can be captured by the previously decoordinated pyridyl ligand (route a), the $\mathrm{NH}$ linking group (route b), or by the nucleophilic $\beta$-carbon atom of the vinylidene ligand (route c). Finally, direct protonation at the ruthenium metal center was also considered (route $\mathrm{d}$ ). Due to the strong acidity of $\mathrm{HBF}_{4} \cdot \mathrm{OEt}_{2}$, we assume an initial barrierless proton transfer; thus, only the relative energies of the protonation products will be discussed for this step.

The reaction starts with complex $\mathbf{1 a}-\mathbf{C l}$, in which the chloride anion has been included, forming a tight ion pair through the $\mathrm{NH}$ linking group of the P,N-ligand. ${ }^{13}$ As mentioned before, route a entails the $\mathrm{N}$-decoordination of the hemilabile $\mathrm{P}, \mathrm{N}$ ligand $^{20}$ and subsequent nitrogen protonation (Scheme 5 ). The vacant site at the ruthenium atom is easily fulfilled by the chloride anion, which can interact with the pyridinium moiety through an intramolecular H-bond contact as in 4a. Such species $4 \mathrm{a}$ has been taken as zero energy. The corresponding rotamer $4 \mathrm{a}^{\prime}$ is $2.5 \mathrm{kcal} \mathrm{mol}^{-1}$ less stable. These (or related) kinds of intermediates with the pyridyl ligand decoordinated, which cannot be formed during the protonation of $\mathbf{1 a - B P \mathbf { h } _ { 4 }}$ due to the absence of the coordinating chloride, might explain the NMR signals observed at low temperature (Figure 2). Species $\mathbf{5} \mathbf{a}$ and $\mathbf{5} \mathbf{a}^{\prime}$ can be found by changing the location of the chloride ligand, but they are less stable $\left(8.9\right.$ and $5.0 \mathrm{kcal} \mathrm{mol}^{-1}$, respectively), since the intramolecular $\mathrm{H} \cdots \mathrm{Cl}$ interaction disappears. Instead, the recently added hydrogen appears close to the ruthenium center, in the range 2.4-2.5 $\AA$. Now, in order to access the electrophilic $\alpha$-carbon, the proton can undergo a kind of umpolung process ${ }^{21}$ to reverse the polarity: that is, to produce a hydride ligand. This process entails the oxidation of the ruthenium metal from the II to IV oxidation state. From $\mathbf{4 a}$ and $\mathbf{4} \mathbf{a}^{\prime}$, neither intermediates nor transition states to transfer the proton to the ruthenium atom were found. However, species $\mathbf{5 a}$ and $\mathbf{5} \mathbf{a}^{\prime}$ can produce hydride complexes $\mathbf{6 a}$ and 6a' involving barriers of 25.7 (TS5a-6a) and $24.4 \mathrm{kcal}$ $\mathrm{mol}^{-1}\left(\mathbf{T S S a}^{\prime}-6 \mathbf{a}^{\prime}\right)$, respectively.

The protonation at the $\mathrm{NH}$ linking group of the $\mathrm{P}, \mathrm{N}$-ligand via route $b$ is considered next (Scheme 6). The resulting products $7 \mathbf{a}$ and $7 \mathbf{a}^{\prime}$ are located at ca. $12 \mathrm{kcal} \mathrm{mol}^{-1}$; 22 thus, they are unlikely to be detected. From here, putative decoordination of phosphorus and subsequent attack on the $\alpha$-carbon are not feasible processes, since they involve high energy barriers (see the detailed discussion in the Supporting Information). Additionally, in line with $\left[\mathrm{BPh}_{4}\right]^{-}$derivatives (Scheme 2), route $c$ describes the formation of the expected carbyne complexes $2 \mathrm{a}$ and $2 \mathrm{a}^{\prime}$, which lie 7.3 and $9.5 \mathrm{kcal} \mathrm{mol}^{-1}$ above 4a, respectively (Scheme 6). To place the hydrogen at the $\alpha$-carbon, transition states for $1,2-\mathrm{H}$ migration processes were computed from $\mathbf{2 a}$ and $\mathbf{2} \mathbf{a}^{\prime}$, leading to $\eta^{2}-\mathrm{CH}$-alkenyl species 8a. Depending on the carbyne rotamer, $2 \mathbf{a}$ or $\mathbf{2} \mathbf{a}^{\prime}$, the alkenyl moiety can adopt a trans (8at) or cis (8ac) configuration. The processes demand ca. $35 \mathrm{kcal} \mathrm{mol}^{-1}$.

Finally, as stated in route $\mathrm{d}$, under strongly acidic conditions the ruthenium metal can eventually accept a proton, changing its oxidation state from II to IV (Scheme 7). The resulting

Scheme 5. Computed Protonation of 1a at the Pyridyl Ligand (Route a) ${ }^{a}$

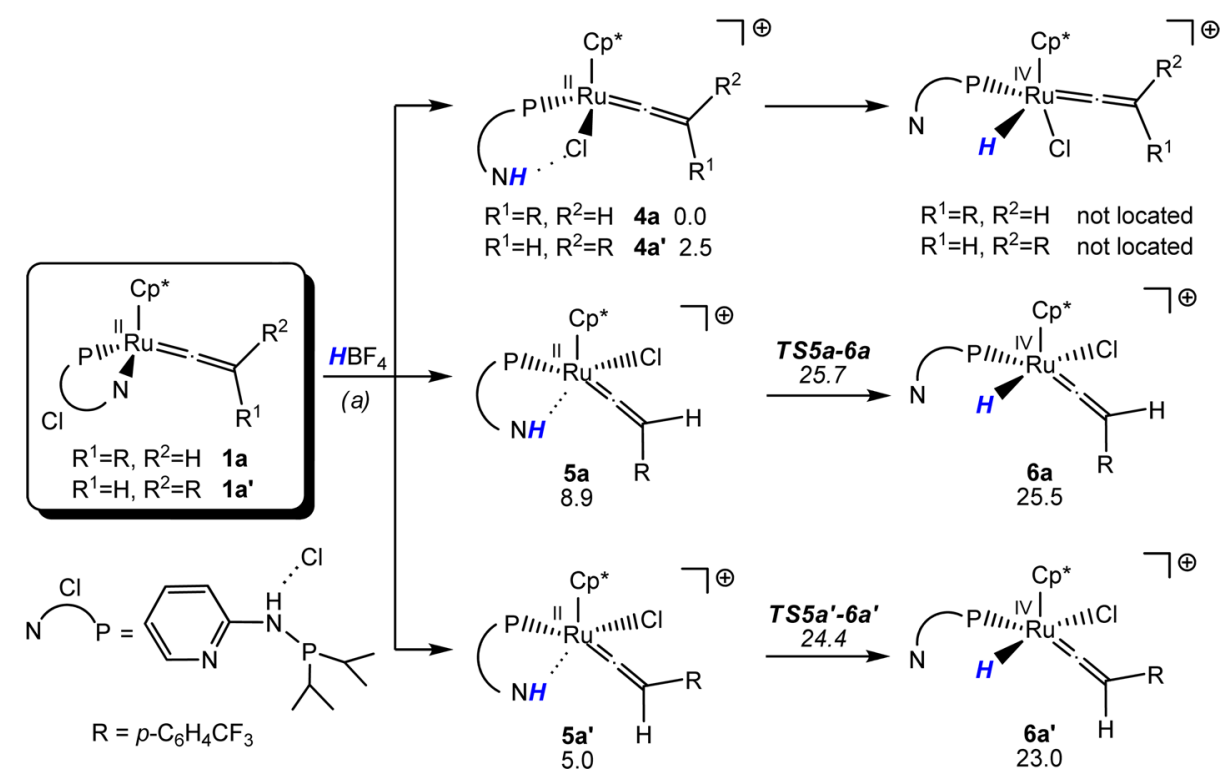

${ }^{a} \Delta G_{\mathrm{DCM}}$ values are given in $\mathrm{kcal} \mathrm{mol}^{-1}$. 
Scheme 6. Computed Protonation of $1 \mathrm{a}$ at the NH Group (Route b) and the $\beta$-Carbon (Route c) ${ }^{a}$

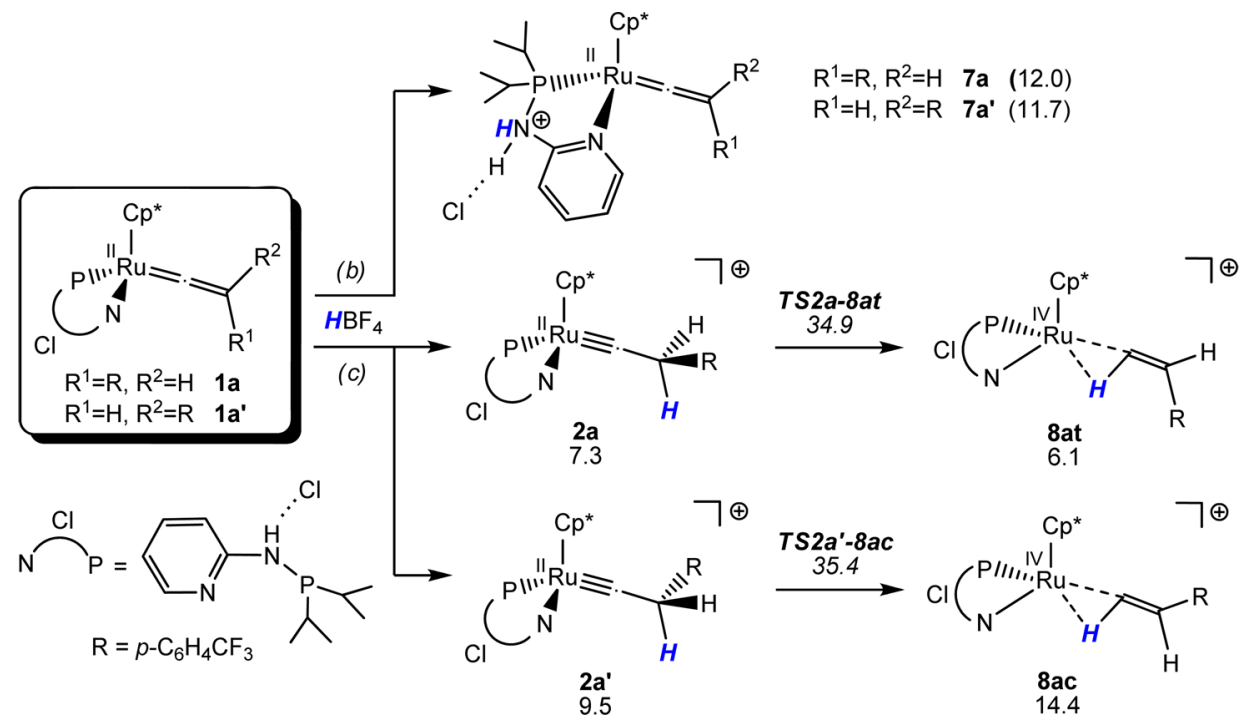

${ }^{a} \Delta G_{\mathrm{DCM}}$ values are given in $\mathrm{kcal} \mathrm{mol}^{-1}$. Values of geometries optimized in DCM solvent are given in parentheses. ${ }^{22}$

Scheme 7. Computed Protonation of $1 \mathrm{a}$ at the Ruthenium Metal (Route d) ${ }^{a}$

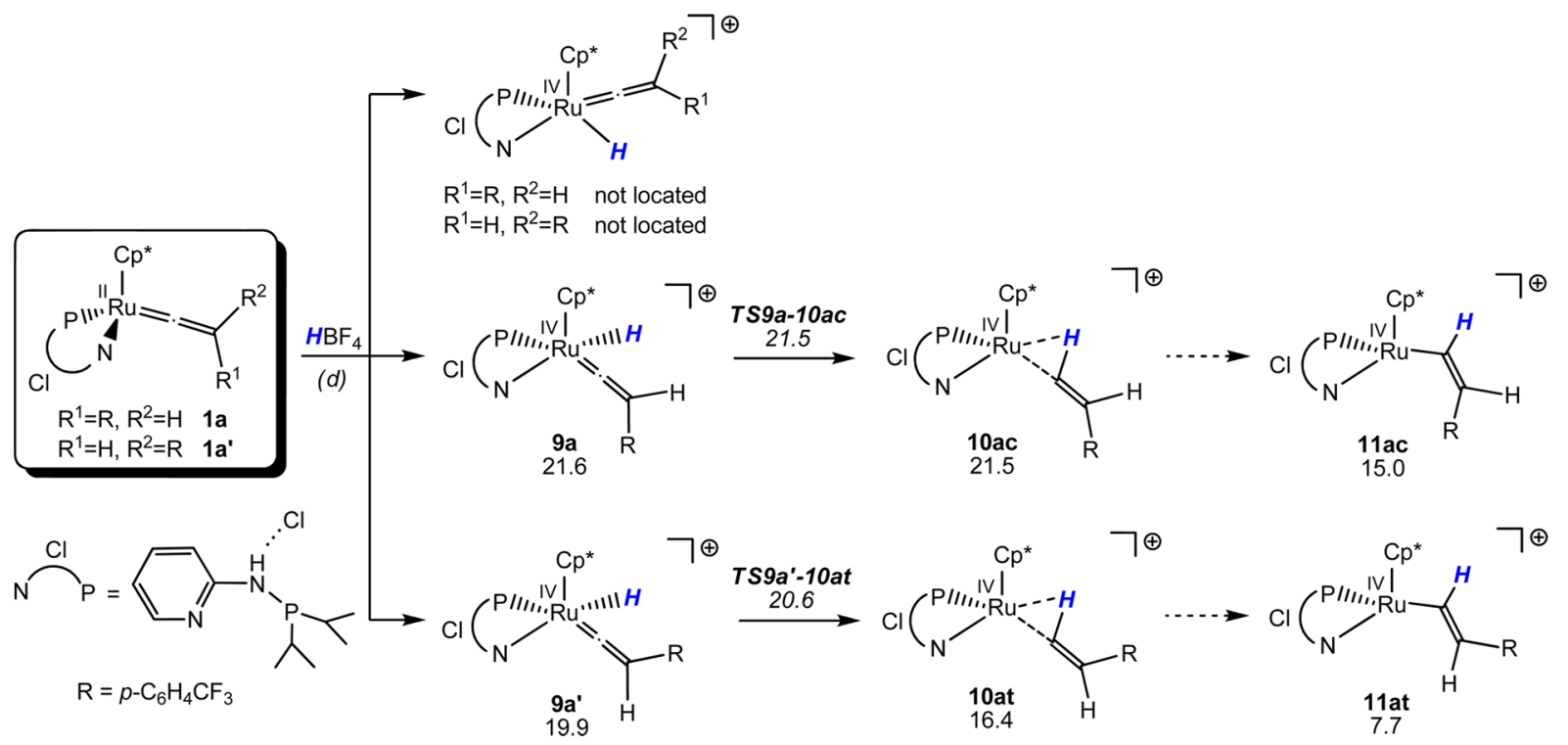

${ }^{a} \Delta G_{\mathrm{DCM}}$ values are given in $\mathrm{kcal} \mathrm{mol}^{-1}$.

hydride complexes $9 \mathrm{a}$ and $9 \mathrm{a}^{\prime}$ are placed 21.6 and $19.9 \mathrm{kcal}$ $\mathrm{mol}^{-1}$ above $4 \mathrm{a}$, respectively. Neither intermediates nor transition states containing the hydride ligand in a pseudotrans position with respect to the phosphorus atom could be found. Similarly to route a, the entering hydrogen has changed its polarity from proton to hydride, and the $\alpha$-carbon can now come into play. Vinylidene ligands in $\mathbf{9 a}$ and $\mathbf{9} \mathbf{a}^{\prime}$ rapidly insert into the $\mathrm{Ru}-\mathrm{H}$ bonds, leading to 16-electron cis- (10ac) and trans- $\eta^{2}$-CH-alkenyl (10at) complexes. The corresponding insertion transition states, TS9a-10ac and TS9a'-10at, are located at 21.5 and $20.6 \mathrm{kcal} \mathrm{mol}^{-1}$; hence, the processes from 9a and $9 \mathrm{a}^{\prime}$ are almost barrierless. The alkenyl ligand is thought to evolve from a $\eta^{2}(\mathrm{C}, \mathrm{H})$ to a $\eta^{1}(\mathrm{C})$ coordination mode, forming species 11ac and 11at. ${ }^{23}$ Although both cis and trans pathways show similar Gibbs energy barriers for the insertion step, the trans derivative 11 at located at $7.7 \mathrm{kcal} \mathrm{mol}^{-1}$ is more stable than $11 \mathrm{ac}$, placed at $15.0 \mathrm{kcal} \mathrm{mol}^{-1}$. This route was also computed on changing the conformation of the isopropyl group of the $\mathrm{P}, \mathrm{N}$ ligand to fit the $\mathrm{X}$-ray structure of $3 \mathrm{~d}$. However, the transition states for the corresponding insertion processes, namely TS9ax-10acx and TS9a'x-10atx, were slightly higher in energy: i.e., 23.6 and $23.1 \mathrm{kcal} \mathrm{mol}^{-1}$ above 4a (see the Supporting Information). A ruthenium protonation and insertion mechanism to form alkenyl compounds has been suggested by Arikawa and co-workers. ${ }^{11}$

Overall, four likely different protonation sites have been computationally evaluated. In route a, the pyridyl ligand accepts the proton and transfers it to ruthenium, involving $24-25 \mathrm{kcal}$ $\mathrm{mol}^{-1}$. In route $\mathrm{b}$, the $\mathrm{NH}$ linking group of the $\mathrm{P}, \mathrm{N}$ ligand accepts the proton, although no feasible reactivity can be envisaged from there. In route $c$, the $\beta$-carbon of the vinylidene ligand can be protonated but the 1,2- $\mathrm{H}$ migration processes require ca. $35 \mathrm{kcal} \mathrm{mol}^{-1}$ and the Gibbs energy barriers can hardly be overcome. In route $\mathrm{d}$, the proton reaches the 
Scheme 8. Computed Mechanisms for the Formation of Alkene Complexes ${ }^{a}$

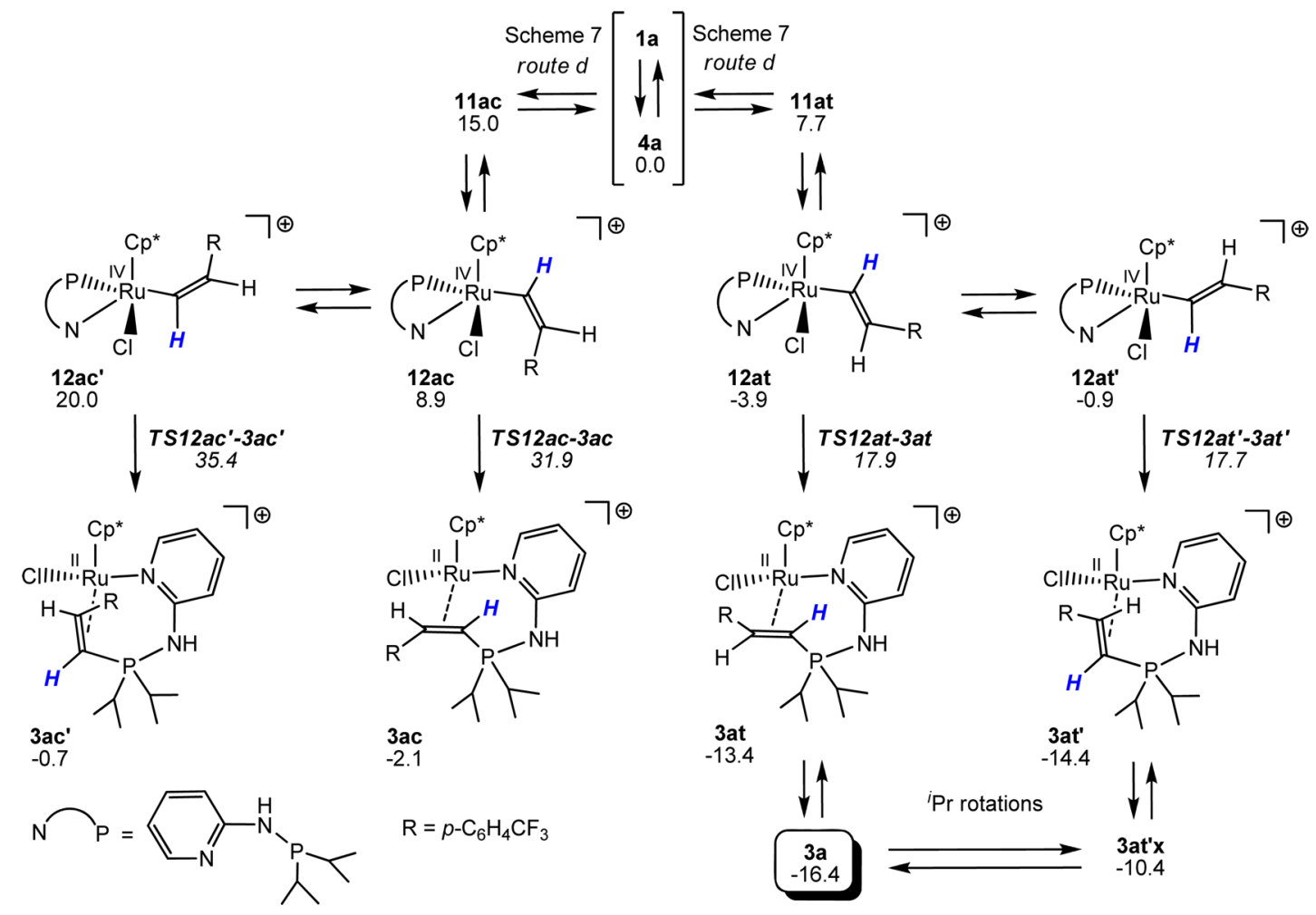

${ }^{a} \Delta G_{\mathrm{DCM}}$ values are given in $\mathrm{kcal} \mathrm{mol}^{-1}$.
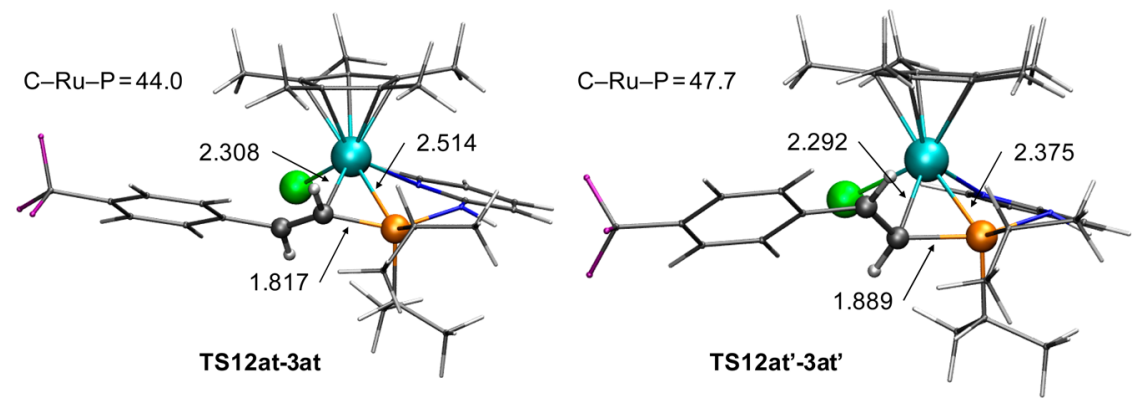

Figure 3. Optimized geometries of the more stable transition states leading to $\mathrm{P}-\mathrm{C}$ bond formation. Bond distances are given in $\AA$ and angles in degrees.

ruthenium atom, forming a hydride species, and the subsequent insertion of the vinylidene ligand into the $\mathrm{Ru}-\mathrm{H}$ bond takes ca. $21 \mathrm{kcal} \mathrm{mol}^{-1}$. Therefore, assuming that the energies for the direct metal protonation are essentially the same as those for the hydride species, ${ }^{24}$ route $\mathrm{d}$ is favored.

Formation of the $P-C$ Bond. Route $\mathrm{d}$ has led to alkenyl intermediates 11a, which are unsaturated 16-electron species. The next step concerns the inclusion of the chloride anion into the first coordination sphere of the metal in order to stabilize the unsaturated species (Scheme 8). The presence of chloride is crucial to drive the reaction, producing the 18-electron complexes 12a. The formation of these species is not possible when a noncoordinating anion such as tetraphenylborate is employed. At this stage, two conformers have been computed, where the alkenyl moiety can assume an $s$-cis (12a) or s-trans $\left(12 \mathrm{a}^{\prime}\right)$ conformation with respect to the $\mathrm{Ru}-\mathrm{Cl}$ bond. For both cis (c) and trans $(\mathbf{t})$ routes, the s-trans species 12ac and 12at are more stable than the s-cis counterparts 12ac' and 12at'. The trans intermediates 12at and 12 at $^{\prime}$ are favored, lying 3.9 and 0.9 $\mathrm{kcal} \mathrm{mol}^{-1}$ below $4 \mathrm{a}$, respectively, whereas the cis intermediates 12ac and 12 $\mathrm{ac}^{\prime}$ are placed 8.9 and $20.0 \mathrm{kcal} \mathrm{mol}^{-1}$ above 4a, respectively. Once the alkenyl species $12 \mathrm{a}$ are produced, they can undergo a $\mathrm{P}-\mathrm{C}$ bond formation, yielding the alkene species 3a (Scheme 8). This process is described as a reductive elimination between phosphine and alkenyl ligands. The cis intermediates $12 \mathrm{ac}$ and $12 \mathrm{ac}^{\prime}$ present high energies, and the corresponding transition states, TS12ac-3ac and TS12 $\mathrm{ac}^{\prime}-3 \mathrm{ac}^{\prime}$, are energetically inaccessible: ca. $32-35 \mathrm{kcal} \mathrm{mol}^{-1}$. On the other hand, for the trans intermediates 12at and 12at' the reductive elimination can take place via TS12at-3at and TS12at'-3at' (Figure 3), involving energies of 21.8 and 21.6 $\mathrm{kcal} \mathrm{mol}^{-1}$ above 12at, respectively.

The higher Gibbs energies of cis species are attributed to steric effects of the aryl group $\mathrm{R}$ with (i) $\mathrm{Cp}^{*}$ and isopropyl moieties in 12ac' and (ii) the $\mathrm{Cl}$ ligand in 12ac, whereas both interactions are absent in the trans counterparts. All the aforementioned transition states yield alkene complexes. Again, the trans products 3at and 3at' $\left(13-14 \mathrm{kcal} \mathrm{mol}^{-1}\right.$ below 4a) 
are more stable than the cis species $3 \mathrm{ac}$ and $3 \mathrm{ac}^{\prime}(1-2 \mathrm{kcal}$ $\mathrm{mol}^{-1}$ below 4a). Eventually, the even more stable alkene complex 3a $\left(-16.4 \mathrm{kcal} \mathrm{mol}^{-1}\right)$, whose $\mathrm{P}, \mathrm{N}$-ligand conformation agrees with that observed in the analogous X-ray structure of $\mathbf{3 d}$, can be obtained from 3 at or $3 \mathbf{a t}^{\prime}$ through proper isopropyl rotations. The $\mathrm{P}-\mathrm{C}$ coupling transition states with the X-ray isopropyl conformation have also been computed, namely TS12atx-3a and TS12at' $\mathbf{x}$-3at' $\mathbf{x}$, but they exhibit higher Gibbs energy barriers of 24.6 and $27.0 \mathrm{kcal} \mathrm{mol}^{-1}$ above 12at, respectively (see the Supporting Information). Likely, either 3at or 3at' is first formed, and then it evolves to 3a. Thus, the resonance observed at $56.9 \mathrm{ppm}$ during the $\mathrm{VT}^{31} \mathrm{P}\left\{{ }^{1} \mathrm{H}\right\} \mathrm{NMR}$ monitoring of the protonation of $\mathbf{1 a}-\mathbf{C l}$ with $\mathrm{HBF}_{4} \cdot \mathrm{OEt}_{2}$ might correspond to either 3at or 3at' (Figure 2). This signal disappears at $298 \mathrm{~K}$, being replaced by another one at $56.7 \mathrm{ppm}$ corresponding to the final product $3 \mathrm{a}$.

To conclude, a reaction mechanism for the formation of the alkene complexes $\mathbf{3 a}-\mathbf{d}$ has been proposed. First, the protonation of vinylidene reactant 1a has been considered to take place at the pyridyl nitrogen (route a, Scheme 5), the NH group of the $\mathrm{P}, \mathrm{N}$ ligand (route $\mathrm{b}, \mathrm{Sch}$ eme 6 ), the $\beta$-carbon (route c, Scheme 6), and the ruthenium metal (route d, Scheme 7). Pyridine decoordination and subsequent nitrogen protonation (route a) form the most stable species $4 a$, but only the metal protonation (route $\mathrm{d}$ ) provides a feasible pathway that demands ca. $21 \mathrm{kcal} \mathrm{mol}^{-1}$ (in comparison to ca. 25 and $35 \mathrm{kcal}$ $\mathrm{mol}^{-1}$ for routes a and c, respectively). This process leads to alkenyl species 12a, which includes the chloride anion directly bound to ruthenium. The $\mathrm{P}-\mathrm{C}$ reductive couplings were computed for both the cis- and trans-alkenyl compounds (Scheme 8). In agreement with experimental studies, the trans derivatives were the most favored, involving barriers of ca. 22 $\mathrm{kcal} \mathrm{mol}^{-1}$. The key steps were also computed using the conformation of the P,N ligand as in the X-ray structure of 3d, but the Gibbs energy barriers were slightly higher.

As has already been demonstrated for the protonation of transition-metal hydrides, ${ }^{25}$ the protonation of a vinylidene complex also introduces a mobile $\mathrm{H}$ center in the coordination sphere of the metal, which shows a $\mathrm{H}^{+} / \mathrm{H}^{-}$duality and can evolve in a variety of ways depending on the reaction conditions. In our case, the presence of a coordinating anion opens up a new reaction pathway, which is not possible when bulkier noncoordinating counteranions are present. Our results expand the kinds of organometallic reactions where the counteranion plays a key role. ${ }^{13,26-28}$

\section{CONCLUSIONS}

The protonation of $\mathrm{Ru}$-vinylidene complexes of the type $\left[\mathrm{Cp} * \mathrm{Ru}=\mathrm{C}=\mathrm{CHR}\left({ }^{\mathrm{i}} \mathrm{Pr}_{2} \mathrm{PNHPy}\right)\right]^{+}$strongly depends on the counteranion. The addition of excess of $\mathrm{HBF}_{4} \cdot \mathrm{OEt}_{2}$ to their tetraphenylborate salts in $\mathrm{CD}_{2} \mathrm{Cl}_{2}$ leads to the dicationic carbyne complexes $\left[\mathrm{Cp} * \mathrm{Ru} \equiv \mathrm{CCH}_{2} \mathrm{R}\left({ }^{\mathrm{i}} \mathrm{Pr}_{2} \mathrm{PNHPy}\right)\right]^{2+}$. In contrast, in the presence of chloride as counteranion, the same reaction yields the novel alkene complexes $[\mathrm{Cp} * \mathrm{RuCl}$ $\left.\left(\kappa^{1}(N), \eta^{2}(C, C)-\mathrm{C}_{5} \mathrm{H}_{4} \mathrm{NNHP} \mathrm{Pr}_{2} \mathrm{CH}=\mathrm{CHR}\right)\right]\left[\mathrm{BF}_{4}\right]$. Among the possible protonation situations, DFT calculations favor a metal protonation and subsequent insertion step. The chloride coordination to the ruthenium center drives the reaction toward the formation of alkenyl complexes. In the presence of noncoordinating anions (e.g., $\left[\mathrm{BPh}_{4}\right]^{-}$), this alternative pathway is not available. Finally, a $\mathrm{P}-\mathrm{C}$ reductive coupling supports the experimentally observed trans-alkene complexes.

\section{EXPERIMENTAL SECTION}

All synthetic operations were performed under a dry dinitrogen or argon atmosphere following conventional Schlenk techniques. Tetrahydrofuran, diethyl ether, and petroleum ether (boiling point range $40-60^{\circ} \mathrm{C}$ ) were obtained oxygen- and water-free from a solvent purification apparatus. Dichloromethane and methanol were of anhydrous quality and were used as received. All solvents were deoxygenated immediately before use. (Diisopropylphosphinyl)(2pyridyl)amine ${ }^{29}$ and the complexes $\left[\mathrm{Cp} * \operatorname{RuCl}\left({ }^{(} \operatorname{Pr}_{2} \mathrm{PNHPy}\right)\right],{ }^{18} \mathbf{1 a}-\mathrm{Cl}$, and $\mathbf{1 a}-\mathbf{B P h}_{4}{ }^{13}$ were prepared according to reported procedures. NMR spectra were taken on spectrometers operating at 400,500 , or 600 $\mathrm{MHz}\left({ }^{1} \mathrm{H}\right.$ frequencies). Chemical shifts are given in ppm from $\mathrm{SiMe}_{4}$ $\left({ }^{1} \mathrm{H}\right.$ and $\left.{ }^{13} \mathrm{C}\left\{{ }^{1} \mathrm{H}\right\}\right), 85 \% \mathrm{H}_{3} \mathrm{PO}_{4}\left({ }^{31} \mathrm{P}\left\{{ }^{1} \mathrm{H}\right\}\right)$, or fluorobenzene $\left({ }^{19} \mathrm{~F}\right) .{ }^{1} \mathrm{H}$ and ${ }^{13} \mathrm{C}\left\{{ }^{1} \mathrm{H}\right\}$ NMR spectroscopic signal assignments were confirmed by ${ }^{1} \mathrm{H}$-gCOSY, DEPT, and gHSQC $\left({ }^{1} \mathrm{H}-{ }^{13} \mathrm{C}\right)$ experiments when required. Microanalyses were performed at the Servicio Central de Ciencia y Tecnología, Universidad de Cádiz.

$\left[\mathrm{Cp} * \mathrm{Ru}=\mathrm{C}=\mathrm{CHR}\left(\mathrm{Pr}_{2} \mathrm{PNHPy}\right)\right][\mathrm{Cl}]\left(\mathrm{R}=\mathrm{Ph}(1 \mathrm{~b}-\mathrm{Cl}), \mathrm{C}_{6} \mathrm{H}_{4} \mathrm{CH}_{3}\right.$ $\left.(1 \mathrm{c}-\mathrm{Cl}), \mathrm{C}_{6} \mathrm{H}_{4} \mathrm{Br}(1 \mathrm{~d}-\mathrm{Cl}), \mathrm{Bu}^{\mathrm{t}}(1 \mathrm{e}-\mathrm{Cl}), \mathrm{H}(1 \mathrm{f}-\mathrm{Cl})\right)$. To a solution of [Cp* $\left.\mathrm{RuCl}\left({ }^{\mathrm{i}} \mathrm{Pr}_{2} \mathrm{PNHPy}\right)\right](0.24 \mathrm{~g}, 0.5 \mathrm{mmol})$ in dichloromethane was added a slight excess over the stoichiometric amount of the corresponding alkyne. For the preparation of $\mathbf{1 f}-\mathbf{C l}, \mathrm{HC} \equiv \mathrm{CSiMe}_{3}$ was used. The mixture was stirred at room temperature for 4-6 h. At the end of this time, the solvent was removed in vacuo, and the resulting solid was washed with petroleum ether until a microcrystalline solid was obtained and then dried in vacuo.

1b-Cl. Yield: 0.34 g, 95\%. Anal. Calcd for $\mathrm{C}_{29} \mathrm{H}_{40} \mathrm{~N}_{2} \mathrm{ClPRu}$ : C, 59.63; H, 6.90; N, 4.80. Found: C, 59.78; H, 6.88; N, 4.73. ${ }^{1} \mathrm{H}$ NMR $\left(400 \mathrm{MHz}, \mathrm{CDCl}_{3}, 298 \mathrm{~K}\right): \delta 0.9-1.4\left(\mathrm{~m}, 12 \mathrm{H}, \mathrm{P}\left(\mathrm{CH}\left(\mathrm{CH}_{3}\right)_{2}\right)_{2}\right)$, $1.61\left(\mathrm{~s}, 15 \mathrm{H}, \mathrm{C}_{5}\left(\mathrm{CH}_{3}\right)_{5}\right), 2.20,2.90\left(\mathrm{~m}, 1 \mathrm{H}\right.$ each, $\left.\mathrm{P}\left(\mathrm{CH}\left(\mathrm{CH}_{3}\right)_{2}\right)_{2}\right)$, $5.07\left(\mathrm{~s}, 1 \mathrm{H}, \mathrm{RuC}=\mathrm{CHC}_{6} \mathrm{H}_{5}\right), 6.54(\mathrm{t}), 7.42(\mathrm{t}), 7.48(\mathrm{~d}), 7.75(\mathrm{~d})(1$ $\mathrm{H}$ each, $\left.\mathrm{C}_{5} \mathrm{H}_{4} \mathrm{~N}\right), 6.63(\mathrm{t}), 6.97(\mathrm{t}), 7.10(\mathrm{~m})\left(5 \mathrm{H}, \mathrm{RuC}=\mathrm{CHC}_{6} \mathrm{H}_{5}\right)$, 10.8 (s br, $1 \mathrm{H}, \mathrm{NH}) .{ }^{31} \mathrm{P}\left\{{ }^{1} \mathrm{H}\right\}$ NMR $\left(161.89 \mathrm{MHz}, \mathrm{CDCl}_{3}, 298 \mathrm{~K}\right): \delta$ 134.4 (s). ${ }^{13} \mathrm{C}\left\{{ }^{1} \mathrm{H}\right\}$ NMR $\left(100.57 \mathrm{MHz}, \mathrm{CDCl}_{3}, 298 \mathrm{~K}\right): \delta 10.6(\mathrm{~s}$, $\left.\mathrm{C}_{5}\left(\mathrm{CH}_{3}\right)_{5}\right), 16.9(\mathrm{~d}), 17.4(\mathrm{~d}), 17.8(\mathrm{~s}), 18.4(\mathrm{~s})\left(\mathrm{P}\left(\mathrm{CH}\left(\mathrm{CH}_{3}\right)_{2}\right)_{2}\right)$, $29.4\left(\mathrm{~d},{ }_{1}^{1} J(\mathrm{C}, \mathrm{P})=21 \mathrm{~Hz}, \mathrm{P}\left(\mathrm{CH}\left(\mathrm{CH}_{3}\right)_{2}\right)\right), 30.3\left(\mathrm{~d},{ }^{1} \mathrm{~J}(\mathrm{C}, \mathrm{P})=37 \mathrm{~Hz}\right.$, $\left.\mathrm{P}\left(\mathrm{CH}\left(\mathrm{CH}_{3}\right)_{2}\right)\right), 101.8\left(\mathrm{~s}, \mathrm{C}_{5}\left(\mathrm{CH}_{3}\right)_{5}\right), 112.2(\mathrm{~d}), 115.2(\mathrm{~s}), 138.3(\mathrm{~s})$, $151.1(\mathrm{~s}), 164.1(\mathrm{~d})\left(\mathrm{C}_{5} \mathrm{H}_{4} \mathrm{~N}\right), 116.1\left(\mathrm{~s}, \mathrm{RuC}=\mathrm{CHC}_{6} \mathrm{H}_{5}\right), 118.1$, 126.0, 128.4, $131.3\left(\mathrm{~s}, \mathrm{RuC}=\mathrm{CHC}_{6} \mathrm{H}_{5}\right), 342.6\left(\mathrm{~d},{ }^{2} \mathrm{~J}(\mathrm{C}, \mathrm{P})=17 \mathrm{~Hz}\right.$, $\mathrm{Ru}=C)$.

1b-Cl. Yield: 0.48 g, 95\%. Anal. Calcd for $\mathrm{C}_{30} \mathrm{H}_{42} \mathrm{~N}_{2} \mathrm{ClPRu}$ : C, 60.24; H, 7.08; N, 4.68. Found: C, 60.38; H, 7.21; N, 4.50. ${ }^{1} \mathrm{H}$ NMR $\left(400 \mathrm{MHz}, \mathrm{CDCl}_{3}, 298 \mathrm{~K}\right): \delta 1.0-1.4\left(\mathrm{~m}, 12 \mathrm{H}, \mathrm{P}\left(\mathrm{CH}\left(\mathrm{CH}_{3}\right)_{2}\right)_{2}\right)$, $1.77\left(\mathrm{~s}, 15 \mathrm{H}, \mathrm{C}_{5}\left(\mathrm{CH}_{3}\right)_{5}\right), 2.22\left(\mathrm{~s}, 3 \mathrm{H}, \mathrm{RuC}=\mathrm{CHC}_{6} \mathrm{H}_{4} \mathrm{CH}_{3}\right), 2.23$, $2.95\left(\mathrm{~m}, 1 \mathrm{H}\right.$ each, $\left.\mathrm{P}\left(\mathrm{CH}\left(\mathrm{CH}_{3}\right)_{2}\right)_{2}\right), 5.08(\mathrm{~s}, 1 \mathrm{H}, \mathrm{RuC}=$ $\left.\mathrm{CHC}_{6} \mathrm{H}_{4} \mathrm{CH}_{3}\right), 6.51(\mathrm{t}), 7.35(\mathrm{t}), 7.43(\mathrm{~d}), 7.70(\mathrm{~d})$ (1 H each, $\left.\mathrm{C}_{5} \mathrm{H}_{4} \mathrm{~N}\right), 6.52,6.86\left(\mathrm{~d},{ }^{3} J(\mathrm{H}, \mathrm{H})=8 \mathrm{~Hz}, 2 \mathrm{H}\right.$ each, $\mathrm{RuC}=$ $\left.\mathrm{CHC}_{6} \mathrm{H}_{4} \mathrm{CH}_{3}\right), 10.7$ (s br, $\left.1 \mathrm{H}, \mathrm{NH}\right) .{ }^{31} \mathrm{P}\left\{{ }^{1} \mathrm{H}\right\}$ NMR $(161.89 \mathrm{MHz}$, $\left.\mathrm{CDCl}_{3}, 298 \mathrm{~K}\right): \delta 134.5(\mathrm{~s}) .{ }^{13} \mathrm{C}\left\{{ }^{1} \mathrm{H}\right\} \mathrm{NMR}\left(100.57 \mathrm{MHz}, \mathrm{CDCl}_{3}, 298\right.$ $\mathrm{K}): \delta 10.6\left(\mathrm{~s}, \mathrm{C}_{5}\left(\mathrm{CH}_{3}\right)_{5}\right), 16.8(\mathrm{~d}), 17.4(\mathrm{~d}), 17.8(\mathrm{~s}), 18.4(\mathrm{~s})$ $\left(\mathrm{P}\left(\mathrm{CH}\left(\mathrm{CH}_{3}\right)_{2}\right)_{2}\right), 20.8\left(\mathrm{~s}, \mathrm{RuC}=\mathrm{CHC}_{6} \mathrm{H}_{4} \mathrm{CH}_{3}\right), 29.4\left(\mathrm{~d},{ }^{1} J(\mathrm{C}, \mathrm{P})=\right.$ $\left.21 \mathrm{~Hz}, \mathrm{P}\left(\mathrm{CH}\left(\mathrm{CH}_{3}\right)_{2}\right)\right), 30.3\left(\mathrm{~d},{ }^{1} \mathrm{~J}(\mathrm{C}, \mathrm{P})=37 \mathrm{~Hz}, \mathrm{P}\left(\mathrm{CH}\left(\mathrm{CH}_{3}\right)_{2}\right)\right)$, $101.7\left(\mathrm{~s}, \mathrm{C}_{5}\left(\mathrm{CH}_{3}\right)_{5}\right), 112.3(\mathrm{~d}), 115.1(\mathrm{~s}), 138.3(\mathrm{~s}), 151.3(\mathrm{~s}), 164.1$ (d) $\left(\mathrm{C}_{5} \mathrm{H}_{4} \mathrm{~N}\right), 117.0\left(\mathrm{~s}, \mathrm{RuC}=\mathrm{CHC}_{6} \mathrm{H}_{4} \mathrm{CH}_{3}\right), 117.2,125.2,126.1$, $129.6\left(\mathrm{~s}, \mathrm{RuC}=\mathrm{CHC}_{6} \mathrm{H}_{4} \mathrm{CH}_{3}\right), 350.2\left(\mathrm{~d},{ }^{2} J(\mathrm{C}, \mathrm{P})=20 \mathrm{~Hz}, \mathrm{Ru}=C\right)$.

1d-Cl. Yield: 0.39 g, 95\%. Anal. Calcd for $\mathrm{C}_{29} \mathrm{H}_{39} \mathrm{~N}_{2} \mathrm{BrClPRu}$ : C, 52.53; H, 5.93; N, 4.23. Found: C, 52.60; H, 6.00; N, 4.22. ${ }^{1} \mathrm{H}$ NMR $\left(400 \mathrm{MHz}, \mathrm{CDCl}_{3}, 298 \mathrm{~K}\right): \delta 0.8-1.3\left(\mathrm{~m}, 12 \mathrm{H}, \mathrm{P}\left(\mathrm{CH}\left(\mathrm{CH}_{3}\right)_{2}\right)_{2}\right)$, $1.69\left(\mathrm{~s}, 15 \mathrm{H}, \mathrm{C}_{5}\left(\mathrm{CH}_{3}\right)_{5}\right), 2.15,2.91\left(\mathrm{~m}, 1 \mathrm{H}\right.$ each, $\left.\mathrm{P}\left(\mathrm{CH}\left(\mathrm{CH}_{3}\right)_{2}\right)_{2}\right)$, $5.07\left(\mathrm{~s}, 1 \mathrm{H}, \mathrm{RuC}=\mathrm{CHC}_{6} \mathrm{H}_{4} \mathrm{Br}\right), 6.63(\mathrm{t}), 7.42(\mathrm{t}), 7.48(\mathrm{~d}), 7.75(\mathrm{~d})$ $\left(1 \mathrm{H}\right.$ each, $\left.\mathrm{C}_{5} \mathrm{H}_{4} \mathrm{~N}\right), 6.53,6.63\left(\mathrm{~d},{ }^{3} \mathrm{~J}(\mathrm{H}, \mathrm{H})=8 \mathrm{~Hz}, 2 \mathrm{H}\right.$ each, $\mathrm{RuC}=$ $\left.\mathrm{CHC}_{6} \mathrm{H}_{4} \mathrm{Br}\right), 10.8(\mathrm{~s}$ br, $1 \mathrm{H}, \mathrm{NH}) .{ }^{31} \mathrm{P}\left\{{ }^{1} \mathrm{H}\right\}$ NMR $(161.89 \mathrm{MHz}$ $\left.\mathrm{CDCl}_{3}, 298 \mathrm{~K}\right): \delta 134.5(\mathrm{~s}) .{ }^{13} \mathrm{C}\left\{{ }^{1} \mathrm{H}\right\} \mathrm{NMR}\left(100.57 \mathrm{MHz}, \mathrm{CDCl}_{3}, 298\right.$ $\mathrm{K}): \delta 10.5\left(\mathrm{~s}, \mathrm{C}_{5}\left(\mathrm{CH}_{3}\right)_{5}\right), 16.7(\mathrm{~d}), 17.3(\mathrm{~d}), 17.6(\mathrm{~s}), 18.3(\mathrm{~s})$ $\left(\mathrm{P}\left(\mathrm{CH}\left(\mathrm{CH}_{3}\right)_{2}\right)_{2}\right), 29.3\left(\mathrm{~d},{ }^{1} \mathrm{~J}(\mathrm{C}, \mathrm{P})=21 \mathrm{~Hz}, \mathrm{P}\left(\mathrm{CH}\left(\mathrm{CH}_{3}\right)_{2}\right)\right), 30.1(\mathrm{~d}$, $\left.{ }^{1} J(\mathrm{C}, \mathrm{P})=37 \mathrm{~Hz}, \mathrm{P}\left(\mathrm{CH}\left(\mathrm{CH}_{3}\right)_{2}\right)\right), 102.2\left(\mathrm{~s}, \mathrm{C}_{5}\left(\mathrm{CH}_{3}\right)_{5}\right), 112.3(\mathrm{~d})$, $115.2(\mathrm{~s}), 138.3(\mathrm{~s}), 151.1(\mathrm{~s}), 164.1(\mathrm{~d})\left(\mathrm{C}_{5} \mathrm{H}_{4} \mathrm{~N}\right), 116.1(\mathrm{~s}, \mathrm{RuC}=$ $\mathrm{CHC}_{6} \mathrm{H}_{4} \mathrm{Br}$ ), 118.1, 126.0, 128.4, $131.3\left(\mathrm{~s}, \mathrm{RuC}=\mathrm{CHC}_{6} \mathrm{H}_{4} \mathrm{Br}\right.$ ), 347.3 $\left(\mathrm{d},{ }^{2} \mathrm{~J}(\mathrm{C}, \mathrm{P})=15 \mathrm{~Hz}, \mathrm{Ru}=\mathrm{C}\right)$. 
1e-Cl. Yield: 0.33 g, 95\%. Anal. Calcd for $\mathrm{C}_{27} \mathrm{H}_{44} \mathrm{~N}_{2} \mathrm{ClPRu}$ : C, 57.48; H, 7.86; N, 4.97. Found: C, 57.56; H, 7.99; N, 4.93. ${ }^{1} \mathrm{H}$ NMR $\left(400 \mathrm{MHz}, \mathrm{CDCl}_{3}, 298 \mathrm{~K}\right): \delta 0.82\left(\mathrm{~s}, 9 \mathrm{H}, \mathrm{RuC}=\mathrm{CHC}\left(\mathrm{CH}_{3}\right)_{3}\right), 0.9-$ $1.4\left(\mathrm{~m}, 12 \mathrm{H}, \mathrm{P}\left(\mathrm{CH}\left(\mathrm{CH}_{3}\right)_{2}\right)_{2}\right), 1.80\left(\mathrm{~s}, 15 \mathrm{H}, \mathrm{C}_{5}\left(\mathrm{CH}_{3}\right)_{5}\right), 2.24,2.93$ (m, $1 \mathrm{H}$ each, $\left.\mathrm{P}\left(\mathrm{CH}\left(\mathrm{CH}_{3}\right)_{2}\right)_{2}\right), 3.99\left(\mathrm{~s}, 1 \mathrm{H}, \mathrm{RuC}=\mathrm{CHC}\left(\mathrm{CH}_{3}\right)_{3}\right)$, $6.49(\mathrm{t}), 7.29(\mathrm{~d}), 7.43(\mathrm{t}), 7.66(\mathrm{~d})\left(1 \mathrm{H}\right.$ each, $\left.\mathrm{C}_{5} \mathrm{H}_{4} \mathrm{~N}\right), 10.8(\mathrm{~s} \mathrm{br}, 1$ $\mathrm{H}, \mathrm{NH}) .{ }^{31} \mathrm{P}\left\{{ }^{1} \mathrm{H}\right\}$ NMR $\left(161.89 \mathrm{MHz}, \mathrm{CDCl}_{3}, 298 \mathrm{~K}\right): \delta 133.8$ (s). ${ }^{13} \mathrm{C}\left\{{ }^{1} \mathrm{H}\right\}$ NMR $\left(100.57 \mathrm{MHz}, \mathrm{CDCl}_{3}, 298 \mathrm{~K}\right): \delta 10.5\left(\mathrm{~s}, \mathrm{C}_{5}\left(\mathrm{CH}_{3}\right)_{5}\right)$, 16.9 (d), 17.4 (d), 18.7 (d), 17.4 (d) $\left(\mathrm{P}\left(\mathrm{CH}\left(\mathrm{CH}_{3}\right)_{2}\right)_{2}\right), 29.5$ (d, $\left.{ }^{1} J(\mathrm{C}, \mathrm{P})=21 \mathrm{~Hz}, \mathrm{P}\left(\mathrm{CH}\left(\mathrm{CH}_{3}\right)_{2}\right)\right), 30.4\left(\mathrm{~d},{ }^{1} J(\mathrm{C}, \mathrm{P})=38 \mathrm{~Hz}\right.$, $\left.\mathrm{P}\left(\mathrm{CH}\left(\mathrm{CH}_{3}\right)_{2}\right)\right), 30.9\left(\mathrm{~s}, \mathrm{RuC}=\mathrm{CHC}\left(\mathrm{CH}_{3}\right)_{3}\right), 31.8 \quad(\mathrm{~s}, \mathrm{RuC}=$ $\left.\mathrm{CHC}\left(\mathrm{CH}_{3}\right)_{3}\right), 100.6\left(\mathrm{~s}, \mathrm{C}_{5}\left(\mathrm{CH}_{3}\right)_{5}\right), 111.4(\mathrm{~d}), 114.7(\mathrm{~s}), 137.7$ (s), $151.3(\mathrm{~s}), 164.1(\mathrm{~d})\left(\mathrm{C}_{5} \mathrm{H}_{4} \mathrm{~N}\right), 123.8\left(\mathrm{~s}, \mathrm{RuC}=\mathrm{CHC}\left(\mathrm{CH}_{3}\right)_{3}\right), 342.6$ $\left(\mathrm{d},{ }^{2} J(\mathrm{C}, \mathrm{P})=17 \mathrm{~Hz}, \mathrm{Ru}=\mathrm{C}\right)$.

1f-Cl. Yield: $0.49 \mathrm{~g}, 95 \%$. Anal. Calcd for $\mathrm{C}_{23} \mathrm{H}_{36} \mathrm{~N}_{2} \mathrm{ClPRu}$ : C, 54.37; $\mathrm{H}, 7.14$; N, 5.51. Found: C, 54.48; H, 7.26; N, 5.43. ${ }^{1} \mathrm{H}$ NMR (400 $\left.\mathrm{MHz}, \mathrm{CDCl}_{3}, 298 \mathrm{~K}\right): \delta$ 0.9-1.4 (m, $\left.12 \mathrm{H}, \mathrm{P}\left(\mathrm{CH}\left(\mathrm{CH}_{3}\right)_{2}\right)_{2}\right), 1.73(\mathrm{~s}$, $\left.15 \mathrm{H}, \mathrm{C}_{5}\left(\mathrm{CH}_{3}\right)_{5}\right), 2.12,2.91\left(\mathrm{~m}, 1 \mathrm{H}\right.$ each, $\left.\mathrm{P}\left(\mathrm{CH}\left(\mathrm{CH}_{3}\right)_{2}\right)_{2}\right), 3.19$ (d, $\left.{ }^{4} \mathrm{~J}(\mathrm{H}, \mathrm{P})=1 \mathrm{~Hz}, 2 \mathrm{H}, \mathrm{RuC}=\mathrm{CH}_{2}\right), 6.41(\mathrm{t}), 7.20(\mathrm{~d}), 7.30(\mathrm{t}), 7.58$ (d) $\left(1 \mathrm{H}\right.$ each, $\left.\mathrm{C}_{5} \mathrm{H}_{4} \mathrm{~N}\right), 10.4(\mathrm{~s}$ br, $1 \mathrm{H}, \mathrm{NH}) .{ }^{31} \mathrm{P}\left\{{ }^{1} \mathrm{H}\right\} \mathrm{NMR}(161.89$ $\left.\mathrm{MHz}, \mathrm{CDCl}_{3}, 298 \mathrm{~K}\right): \delta 135.8(\mathrm{~s}) .{ }^{13} \mathrm{C}\left\{{ }^{1} \mathrm{H}\right\} \mathrm{NMR}(100.57 \mathrm{MHz}$, $\left.\mathrm{CDCl}_{3}, 298 \mathrm{~K}\right): \delta 10.5\left(\mathrm{~s}, \mathrm{C}_{5}\left(\mathrm{CH}_{3}\right)_{5}\right), 16.5(\mathrm{~d}), 17.0(\mathrm{~d}), 17.7(\mathrm{~s}), 18.1$ (s) $\left(\mathrm{P}\left(\mathrm{CH}\left(\mathrm{CH}_{3}\right)_{2}\right)_{2}\right), 29.0\left(\mathrm{~d},{ }_{1}^{1} J(\mathrm{C}, \mathrm{P})=17 \mathrm{~Hz}, \mathrm{P}\left(\mathrm{CH}\left(\mathrm{CH}_{3}\right)_{2}\right)\right), 29.3$ $\left(\mathrm{d},{ }^{1} \mathrm{~J}(\mathrm{C}, \mathrm{P})=33 \mathrm{~Hz}, \mathrm{P}\left(\mathrm{CH}\left(\mathrm{CH}_{3}\right)_{2}\right)\right), 92.3\left(\mathrm{~s}, \mathrm{RuC}=\mathrm{CH}_{2}\right), 100.0(\mathrm{~s}$, $\left.\mathrm{C}_{5}\left(\mathrm{CH}_{3}\right)_{5}\right), 111.9(\mathrm{~d}), 115.0(\mathrm{~s}), 137.8(\mathrm{~s}), 151.0(\mathrm{~s}), 163.6$ (d) $\left(\mathrm{C}_{5} \mathrm{H}_{4} \mathrm{~N}\right), 342.6\left(\mathrm{~d},{ }^{2} J(\mathrm{C}, \mathrm{P})=14 \mathrm{~Hz}, \mathrm{Ru}=\mathrm{C}\right)$.

$\left[\mathrm{Cp} * \mathrm{Ru}=\mathrm{C}=\mathrm{CHR}\left(\mathrm{P}_{2} \mathrm{PNHPy}\right]\left[\mathrm{BPh}_{4}\right]\left(\mathrm{R}=\mathrm{Ph}\left(1 \mathrm{~b}-\mathrm{BPh}_{4}\right)\right.\right.$, $\mathrm{C}_{6} \mathrm{H}_{4} \mathrm{CH}_{3}\left(1 \mathrm{c}-\mathrm{BPh}_{4}\right), \mathrm{C}_{6} \mathrm{H}_{4} \mathrm{Br}\left(1 \mathrm{~d}-\mathrm{BPh}_{4}\right), \mathrm{Bu}^{\mathrm{t}}\left(1 \mathrm{e}-\mathrm{BPh}_{4}\right), \mathrm{H}$ (1f$\left.\left.\mathrm{BPh}_{4}\right)\right)$. To a solution of the corresponding vinylidene complex $\mathbf{1 b}$ Cl-1f-Cl (ca. $0.4 \mathrm{mmol})$ in $\mathrm{MeOH}(8 \mathrm{~mL})$ was added an excess of solid $\mathrm{NaBPh}_{4}(0.2 \mathrm{~g}$, ca. $0.6 \mathrm{mmol})$. The mixture was stirred for $2 \mathrm{~h}$. A precipitate was obtained. It was filtered, washed with EtOH and petroleum ether, and dried in vacuo. The products were recrystallized from acetone/ethanol or dichloromethane/petroleum ether mixtures.

$1 b-B P h_{4}$. Yield: $0.28 \mathrm{~g}, 81 \%$. Anal. Calcd for $\mathrm{C}_{53} \mathrm{H}_{60} \mathrm{~N}_{2} \mathrm{BPRu}$ : C, 73.34; H, 6.97; N, 3.23. Found: C, 73.14; H, 6.98; N, 3.04. ${ }^{1} \mathrm{H}$ NMR $\left(500 \mathrm{MHz}, \mathrm{CDCl}_{3}, 298 \mathrm{~K}\right): \delta 0.77-1.11\left(\mathrm{~m}, 12 \mathrm{H}, \mathrm{P}\left(\mathrm{CH}\left(\mathrm{CH}_{3}\right)_{2}\right)_{2}\right)$, $1.74\left(\mathrm{~s}, 15 \mathrm{H}, \mathrm{C}_{5}\left(\mathrm{CH}_{3}\right)_{5}\right), 2.05,2.56\left(\mathrm{~m}, 1 \mathrm{H}\right.$ each, $\left.\mathrm{P}\left(\mathrm{CH}\left(\mathrm{CH}_{3}\right)_{2}\right)_{2}\right)$, $5.05(\mathrm{~d} b r, 1 \mathrm{H}, \mathrm{NH}), 5.15\left(\mathrm{~d},{ }^{4} J(\mathrm{H}, \mathrm{P})=1.5 \mathrm{~Hz}, 1 \mathrm{H}, \mathrm{RuC}=\right.$ $\left.\mathrm{CHC}_{6} \mathrm{H}_{5}\right), 6.05(\mathrm{~d}), 6.52(\mathrm{t}), 7.12(\mathrm{t}), 7.41(\mathrm{~d})\left(1 \mathrm{H}\right.$ each, $\left.\mathrm{C}_{5} \mathrm{H}_{4} \mathrm{~N}\right)$, $6.64(\mathrm{~d}), 7.00(\mathrm{t}), 7.12(\mathrm{~m})\left(5 \mathrm{H}, \mathrm{RuC}=\mathrm{CHC}_{6} \mathrm{H}_{5}\right) \cdot{ }^{31} \mathrm{P}\left\{{ }^{1} \mathrm{H}\right\} \mathrm{NMR}$ $\left(202.31 \mathrm{MHz}, \mathrm{CDCl}_{3}, 298 \mathrm{~K}\right): \delta 133.3(\mathrm{~s}) .{ }^{13} \mathrm{C}\left\{{ }^{1} \mathrm{H}\right\}$ NMR $(125.67$ $\left.\mathrm{MHz}, \mathrm{CDCl}_{3}, 298 \mathrm{~K}\right): \delta 10.7\left(\mathrm{~s}, \mathrm{C}_{5}\left(\mathrm{CH}_{3}\right)_{5}\right), 16.1(\mathrm{~d}), 17.0(\mathrm{~d}), 17.6$ (s), 18.3 (s) $\left(\mathrm{P}\left(\mathrm{CH}\left(\mathrm{CH}_{3}\right)_{2}\right)_{2}\right), 29.1\left(\mathrm{~d},{ }^{1} \mathrm{~J}(\mathrm{C}, \mathrm{P})=20 \mathrm{~Hz}\right.$, $\left.\mathrm{P}\left(\mathrm{CH}\left(\mathrm{CH}_{3}\right)_{2}\right)\right), 30.0\left(\mathrm{~d},{ }^{1} \mathrm{~J}(\mathrm{C}, \mathrm{P})=36 \mathrm{~Hz}, \mathrm{P}\left(\mathrm{CH}\left(\mathrm{CH}_{3}\right)_{2}\right)\right), 102.5(\mathrm{~s}$, $\left.\mathrm{C}_{5}\left(\mathrm{CH}_{3}\right)_{5}\right), 111.5(\mathrm{~d}), 116.6(\mathrm{~s}), 139.8(\mathrm{~s}), 151.8(\mathrm{~s}), 162.6(\mathrm{~d})$ $\left(C_{5} \mathrm{H}_{4} \mathrm{~N}\right), 117.6\left(\mathrm{~s}, \mathrm{RuC}=\mathrm{CHC}_{6} \mathrm{H}_{5}\right), 125.1,126.1,128.8(\mathrm{~s}, \mathrm{RuC}=$ $\left.\mathrm{CHC}_{6} \mathrm{H}_{5}\right), 350.8\left(\mathrm{~d},{ }^{2} J(\mathrm{C}, \mathrm{P})=16 \mathrm{~Hz}, \mathrm{Ru}=C\right)$.

1c-BPh . Yield: $0.27 \mathrm{~g}, 77 \%$. Anal. Calcd for $\mathrm{C}_{54} \mathrm{H}_{62} \mathrm{~N}_{2} \mathrm{BPRu}$ : C, 73.54; H, 7.09; N, 3.18. Found: C, 73.42; H, 7.11; N, 3.10. ${ }^{1} \mathrm{H}$ NMR $\left(400 \mathrm{MHz}, \mathrm{CD}_{2} \mathrm{Cl}_{2}, 298 \mathrm{~K}\right): \delta 1.01-1.29\left(\mathrm{~m}, 12 \mathrm{H}, \mathrm{P}\left(\mathrm{CH}\left(\mathrm{CH}_{3}\right)_{2}\right)_{2}\right)$, $1.92\left(\mathrm{~s}, 15 \mathrm{H}, \mathrm{C}_{5}\left(\mathrm{CH}_{3}\right)_{5}\right), 2.30,2.78\left(\mathrm{~m}, 1 \mathrm{H}\right.$ each, $\left.\mathrm{P}\left(\mathrm{CH}\left(\mathrm{CH}_{3}\right)_{2}\right)_{2}\right)$, $2.42\left(\mathrm{~s}, 3 \mathrm{H}, \mathrm{RuC}=\mathrm{CHC}_{6} \mathrm{H}_{4} \mathrm{CH}_{3}\right), 3.48(\mathrm{~s}, 1 \mathrm{H}, \mathrm{RuC}=$ $\left.\mathrm{CHC}_{6} \mathrm{H}_{4} \mathrm{CH}_{3}\right), 5.60(\mathrm{~s} \mathrm{br}, 1 \mathrm{H}, \mathrm{NH}), 6.52(\mathrm{~d}), 6.78(\mathrm{t}), 7.45(\mathrm{t})$, $7.66(\mathrm{~d})\left(1 \mathrm{H}\right.$ each, $\left.\mathrm{C}_{5} \mathrm{H}_{4} \mathrm{~N}\right), 6.70,7.09\left(\mathrm{~d},{ }^{3} \mathrm{~J}(\mathrm{H}, \mathrm{H})=8 \mathrm{~Hz}, 2 \mathrm{H}\right.$ each, $\left.\mathrm{RuC}=\mathrm{CHC}_{6} \mathrm{H}_{4} \mathrm{CH}_{3}\right) .{ }^{31} \mathrm{P}\left\{{ }^{1} \mathrm{H}\right\} \mathrm{NMR}\left(161.89 \mathrm{MHz}, \mathrm{CD}_{2} \mathrm{Cl}_{2}, 298 \mathrm{~K}\right):$ $\delta 136.5$ (s). ${ }^{13} \mathrm{C}\left\{{ }^{1} \mathrm{H}\right\}$ NMR $\left(100.57 \mathrm{MHz}, \mathrm{CD}_{2} \mathrm{Cl}_{2}, 298 \mathrm{~K}\right): \delta 10.8(\mathrm{~s}$, $\left.\mathrm{C}_{5}\left(\mathrm{CH}_{3}\right)_{5}\right), 16.3,17.2,17.9,18.3\left(\mathrm{~s}, \mathrm{P}\left(\mathrm{CH}\left(\mathrm{CH}_{3}\right)_{2}\right)_{2}\right), 21.1(\mathrm{~s}, \mathrm{RuC}=$ $\left.\mathrm{CHC}_{6} \mathrm{H}_{4} \mathrm{CH}_{3}\right), 29.5\left(\mathrm{~d},{ }^{1} \mathrm{~J}(\mathrm{C}, \mathrm{P})=19 \mathrm{~Hz}, \mathrm{P}\left(\mathrm{CH}\left(\mathrm{CH}_{3}\right)_{2}\right)\right), 30.7(\mathrm{~d}$, $\left.{ }^{1} J(\mathrm{C}, \mathrm{P})=37 \mathrm{~Hz}, \mathrm{P}\left(\mathrm{CH}\left(\mathrm{CH}_{3}\right)_{2}\right)\right), 102.9\left(\mathrm{~s}, \mathrm{C}_{5}\left(\mathrm{CH}_{3}\right)_{5}\right), 111.0$ (d), $117.0(\mathrm{~s}), 136.2(\mathrm{~s}), 152.8(\mathrm{~s}), 162.0(\mathrm{~d})\left(\mathrm{C}_{5} \mathrm{H}_{4} \mathrm{~N}\right), 117.5(\mathrm{~s}, \mathrm{RuC}=$ $\left.\mathrm{CHC}_{6} \mathrm{H}_{4} \mathrm{CH}_{3}\right), 125.3,125.6,129.7\left(\mathrm{~s}, \mathrm{RuC}=\mathrm{CHC}_{6} \mathrm{H}_{4} \mathrm{CH}_{3}\right), 352.5(\mathrm{~d}$, $\left.{ }^{2} J(\mathrm{C}, \mathrm{P})=15 \mathrm{~Hz}, \mathrm{Ru}=C\right)$.

$1 d-B P h_{4}$. Yield: $0.31 \mathrm{~g}, 82 \%$. Anal. Calcd for $\mathrm{C}_{53} \mathrm{H}_{59} \mathrm{~N}_{2} \mathrm{BBrPRu}$ : C, 67.23; H, 6.28; N, 2.96. Found: C, 66.93; H, 6.15; N, 2.92. ${ }^{1} \mathrm{H}$ NMR $\left(400 \mathrm{MHz}, \mathrm{CDCl}_{3}, 298 \mathrm{~K}\right): \delta 0.91-1.24\left(\mathrm{~m}, 12 \mathrm{H}, \mathrm{P}\left(\mathrm{CH}\left(\mathrm{CH}_{3}\right)_{2}\right)_{2}\right)$, $1.85\left(\mathrm{~s}, 15 \mathrm{H}, \mathrm{C}_{5}\left(\mathrm{CH}_{3}\right)_{5}\right), 2.22,2.73\left(\mathrm{~m}, 1 \mathrm{H}\right.$ each, $\left.\mathrm{P}\left(\mathrm{CH}\left(\mathrm{CH}_{3}\right)_{2}\right)_{2}\right)$, $3.43\left(\mathrm{~s}, 1 \mathrm{H}, \mathrm{RuC}=\mathrm{CHC}_{6} \mathrm{H}_{4} \mathrm{Br}\right), 5.21(\mathrm{~s}, 1 \mathrm{H}, \mathrm{NH}), 6.52(\mathrm{~d}), 6.72(\mathrm{t})$, $7.41(\mathrm{t}), 7.57(\mathrm{~d})\left(1 \mathrm{H}\right.$ each, $\left.\mathrm{C}_{5} \mathrm{H}_{4} \mathrm{~N}\right), 6.61,7.31\left(\mathrm{~d},{ }^{3} \mathrm{~J}(\mathrm{H}, \mathrm{H})=8 \mathrm{~Hz}, 2\right.$ $\mathrm{H}$ each, $\left.\mathrm{RuC}=\mathrm{CHC}_{6} \mathrm{H}_{4} \mathrm{Br}\right) .{ }^{31} \mathrm{P}\left\{{ }^{1} \mathrm{H}\right\}$ NMR $\left(161.89 \mathrm{MHz}, \mathrm{CDCl}_{3}\right.$,
$298 \mathrm{~K}): \delta 136.2(\mathrm{~s}) .{ }^{13} \mathrm{C}\left\{{ }^{1} \mathrm{H}\right\} \mathrm{NMR}\left(100.57 \mathrm{MHz}, \mathrm{CDCl}_{3}, 298 \mathrm{~K}\right): \delta$ $10.9\left(\mathrm{~s}, \quad \mathrm{C}_{5}\left(\mathrm{CH}_{3}\right)_{5}\right), 16.4(\mathrm{~s}), 17.3(\mathrm{~s}), 17.9$ (s), 18.4 (s) $\left(\mathrm{P}\left(\mathrm{CH}\left(\mathrm{CH}_{3}\right)_{2}\right)_{2}\right), 29.5\left(\mathrm{~d},{ }^{1} \mathrm{~J}(\mathrm{C}, \mathrm{P})=19 \mathrm{~Hz}, \mathrm{P}\left(\mathrm{CH}\left(\mathrm{CH}_{3}\right)_{2}\right)\right), 30.6$ $\left({ }^{1},{ }^{1} \mathrm{~J}(\mathrm{C}, \mathrm{P})=35 \mathrm{~Hz}, \mathrm{P}\left(\mathrm{CH}\left(\mathrm{CH}_{3}\right)_{2}\right)\right), 103.3\left(\mathrm{~s}, \mathrm{C}_{5}\left(\mathrm{CH}_{3}\right)_{5}\right), 111.3$ (d), $118.9(\mathrm{~s}), 140.2(\mathrm{~s}), 152.6(\mathrm{~s}), 162.3(\mathrm{~d})\left(\mathrm{C}_{5} \mathrm{H}_{4} \mathrm{~N}\right), 117.1(\mathrm{~s}, \mathrm{RuC}=$ $\left.\mathrm{CHC}_{6} \mathrm{H}_{4} \mathrm{Br}\right), 126.8,128.7,132.0\left(\mathrm{~s}, \mathrm{RuC}=\mathrm{CHC}_{6} \mathrm{H}_{4} \mathrm{Br}\right), 349.6(\mathrm{~d}$, $\left.{ }^{2} J(\mathrm{C}, \mathrm{P})=16.3 \mathrm{~Hz}, \mathrm{Ru}=\mathrm{C}\right)$.

1e-BPh . Yield: $0.28 \mathrm{~g}, 83 \%$. Anal. Calcd for $\mathrm{C}_{51} \mathrm{H}_{64} \mathrm{~N}_{2} \mathrm{BPRu}$ : C, 72.24; H, 7.61; N, 3.30. Found: C, 72.04; H, 7.54; N, 3.09. ${ }^{1} \mathrm{H}$ NMR $\left(400 \mathrm{MHz}, \mathrm{CDCl}_{3}, 298 \mathrm{~K}\right): \delta 0.87\left(\mathrm{~s}, 9 \mathrm{H}, \mathrm{RuC}=\mathrm{CHC}\left(\mathrm{CH}_{3}\right)_{3}\right)$, 0.94-1.24 (m, $\left.12 \mathrm{H}, \mathrm{P}\left(\mathrm{CH}\left(\mathrm{CH}_{3}\right)_{2}\right)_{2}\right), 1.84\left(\mathrm{~s}, 15 \mathrm{H}, \mathrm{C}_{5}\left(\mathrm{CH}_{3}\right)_{5}\right), 2.20$, $2.76\left(\mathrm{~m}, 1 \mathrm{H}\right.$ each, $\left.\mathrm{P}\left(\mathrm{CH}\left(\mathrm{CH}_{3}\right)_{2}\right)_{2}\right), 4.11(\mathrm{~s}, 1 \mathrm{H}, \mathrm{RuC}=$ $\left.\mathrm{CHC}\left(\mathrm{CH}_{3}\right)_{3}\right), 5.80(\mathrm{~s} \mathrm{br}, 1 \mathrm{H}, \mathrm{NH}), 6.53(\mathrm{~d}), 6.62(\mathrm{t}), 7.39(\mathrm{~m})(4$ $\left.\mathrm{H}, \mathrm{C}_{5} \mathrm{H}_{4} \mathrm{~N}\right) \cdot{ }^{31} \mathrm{P}\left\{{ }^{1} \mathrm{H}\right\}$ NMR $\left(161.89 \mathrm{MHz}, \mathrm{CDCl}_{3}, 298 \mathrm{~K}\right): \delta 135.25$ (s). ${ }^{13} \mathrm{C}\left\{{ }^{1} \mathrm{H}\right\}$ NMR $\left(100.57 \mathrm{MHz}, \mathrm{CDCl}_{3}, 298 \mathrm{~K}\right): \delta 10.9(\mathrm{~s}$, $\left.\mathrm{C}_{5}\left(\mathrm{CH}_{3}\right)_{5}\right), 16.6$ (d), 17.5 (d), 17.8 (d), 18.9 (d) $\left(\mathrm{P}\left(\mathrm{CH}\left(\mathrm{CH}_{3}\right)_{2}\right)_{2}\right)$, $30.0\left(\mathrm{~d},{ }^{1} J(\mathrm{C}, \mathrm{P})=20 \mathrm{~Hz}, \mathrm{P}\left(\mathrm{CH}\left(\mathrm{CH}_{3}\right)_{2}\right)\right), 30.9\left(\mathrm{~d},{ }^{1} J(\mathrm{C}, \mathrm{P})=36 \mathrm{~Hz}\right.$, $\left.\mathrm{P}\left(\mathrm{CH}\left(\mathrm{CH}_{3}\right)_{2}\right)\right), 31.8 \quad\left(\mathrm{~s}, \mathrm{RuC}=\mathrm{CHC}\left(\mathrm{CH}_{3}\right)_{3}\right), 32.3(\mathrm{~s}, \mathrm{RuC}=$ $\left.\mathrm{CHC}\left(\mathrm{CH}_{3}\right)_{3}\right), 102.1\left(\mathrm{~s}, \mathrm{C}_{5}\left(\mathrm{CH}_{3}\right)_{5}\right), 110.3(\mathrm{~d}), 116.9(\mathrm{~s}), 139.8(\mathrm{~s})$, $153.1(\mathrm{~s}), 161.8(\mathrm{~d})\left(\mathrm{C}_{5} \mathrm{H}_{4} \mathrm{~N}\right), 122.2\left(\mathrm{~s}, \mathrm{RuC}=\mathrm{CHC}\left(\mathrm{CH}_{3}\right)_{3}\right), 345.0$ $\left(\mathrm{d},{ }^{2} J(\mathrm{C}, \mathrm{P})=17 \mathrm{~Hz}, \mathrm{Ru}=\mathrm{C}\right)$.

$1 f-B P h_{4}$. Yield: $0.25 \mathrm{~g}, 79 \%$. Anal. Calcd for $\mathrm{C}_{47} \mathrm{H}_{56} \mathrm{~N}_{2} \mathrm{BPRu}$ : C, 71.29; H, 7.13; N, 3.54. Found: C, 70.94; H, 6.96; N, 3.12. ${ }^{1} \mathrm{H}$ NMR $\left(500 \mathrm{MHz}, \mathrm{CD}_{2} \mathrm{Cl}_{2}, 298 \mathrm{~K}\right): \delta 0.90-1.23\left(\mathrm{~m}, 12 \mathrm{H}, \mathrm{P}\left(\mathrm{CH}\left(\mathrm{CH}_{3}\right)_{2}\right)_{2}\right)$, $1.83\left(\mathrm{~s}, 15 \mathrm{H}, \mathrm{C}_{5}\left(\mathrm{CH}_{3}\right)_{5}\right), 2.19,2.65\left(\mathrm{~m}, 1 \mathrm{H}\right.$ each, $\left.\mathrm{P}\left(\mathrm{CH}\left(\mathrm{CH}_{3}\right)_{2}\right)_{2}\right)$, $3.42\left(\mathrm{~d},{ }^{4} \mathrm{~J}(\mathrm{H}, \mathrm{P})=2.5 \mathrm{~Hz}, 2 \mathrm{H}, \mathrm{RuC}=\mathrm{CH}_{2}\right), 5.58(\mathrm{~s} \mathrm{br}, 1 \mathrm{H}, \mathrm{NH})$ 6.55 (d), $6.63(\mathrm{t}), 7.39$ (d), 7.41 (d) $\left(1 \mathrm{H}\right.$ each, $\left.\mathrm{C}_{5} \mathrm{H}_{4} \mathrm{~N}\right) .{ }^{31} \mathrm{P}\left\{{ }^{1} \mathrm{H}\right\}$ NMR (202.31 MHz, $\left.\mathrm{CD}_{2} \mathrm{Cl}_{2}, 298 \mathrm{~K}\right): \delta 137.8(\mathrm{~s}) .{ }^{13} \mathrm{C}\left\{{ }^{1} \mathrm{H}\right\}$ NMR $\left(125.67 \mathrm{MHz}, \mathrm{CD}_{2} \mathrm{Cl}_{2}, 298 \mathrm{~K}\right): \delta 10.7\left(\mathrm{~s}, \mathrm{C}_{5}\left(\mathrm{CH}_{3}\right)_{5}\right), 16.2(\mathrm{~d}), 17.3$ (d), $18.1(\mathrm{~s}), 18.2(\mathrm{~s})\left(\mathrm{P}\left(\mathrm{CH}\left(\mathrm{CH}_{3}\right)_{2}\right)_{2}\right), 29.2\left(\mathrm{~d},{ }^{1} \mathrm{~J}(\mathrm{C}, \mathrm{P})=25.1 \mathrm{~Hz}\right.$, $\left.\mathrm{P}\left(\mathrm{CH}\left(\mathrm{CH}_{3}\right)_{2}\right)\right), 30.1\left(\mathrm{~d},{ }^{1} \mathrm{~J}(\mathrm{C}, \mathrm{P})=44 \mathrm{~Hz} \mathrm{~Hz}, \mathrm{P}\left(\mathrm{CH}\left(\mathrm{CH}_{3}\right)_{2}\right)\right), 93.5(\mathrm{~s}$, $\left.\mathrm{RuC}=\mathrm{CH}_{2}\right), 101.4\left(\mathrm{~d}, J=2.5 \mathrm{~Hz}, \mathrm{C}_{5}\left(\mathrm{CH}_{3}\right)_{5}\right), 110.8(\mathrm{~d}), 117.1(\mathrm{~s})$, $139.7(\mathrm{~s}), 152.8(\mathrm{~s}), 161.8(\mathrm{~d})\left(\mathrm{C}_{5} \mathrm{H}_{4} \mathrm{~N}\right), 344.1\left(\mathrm{~d},{ }^{2} \mathrm{~J}(\mathrm{C}, \mathrm{P})=14.5 \mathrm{~Hz}\right.$, $\mathrm{Ru}=\mathrm{C})$.

$\left[\mathrm{Cp} * \mathrm{Ru} \equiv \mathrm{CCH}_{2} \mathrm{R}\left({ }^{\mathrm{P} P r_{2}} \mathrm{PNHPy}\right)\right]^{2+}\left(\mathrm{R}=\mathrm{C}_{6} \mathrm{H}_{4} \mathrm{CF}_{3}(2 \mathrm{a}), \mathrm{Ph}(2 \mathrm{~b})\right.$, $\left.\mathrm{C}_{6} \mathrm{H}_{4} \mathrm{CH}_{3}(2 \mathrm{c}), \mathrm{C}_{6} \mathrm{H}_{4} \mathrm{Br}^{2}(2 \mathrm{~d}), \mathrm{Bu}^{\mathrm{t}}(2 \mathrm{e}), \mathrm{H}(2 \mathrm{f})\right)$. Solutions of the respective vinylidene complexes $\mathbf{1 a}-\mathbf{B P h}_{4}-\mathbf{l f}-\mathbf{B P h}_{4}(0.1 \mathrm{mmol})$ in $\mathrm{CD}_{2} \mathrm{Cl}_{2}$, prepared under an argon or dinitrogen atmosphere in NMR tubes, were frozen by immersion into liquid nitrogen. Then, an excess of $\mathrm{HBF}_{4} \cdot \mathrm{OEt}_{2}(42 \mu \mathrm{L}$, ca. $0.3 \mathrm{mmol})$ was added using a micropipet. The solvent was allowed to melt. Then, the tubes were shaken, to mix the reagents, and stored in an ethanol/liquid nitrogen bath. The samples prepared in this way were studied by NMR at low temperatures. The sample was removed from the bath and inserted into the precooled probe of the NMR spectrometer at $193 \mathrm{~K}$. Once shims were adjusted, the probe was warmed to the desired temperature. The NMR temperature controller was previously calibrated against a methanol sample, with the reproducibility being $\pm 0.5^{\circ} \mathrm{C}$.

2a. ${ }^{1} \mathrm{H}$ NMR ( $\left.500 \mathrm{MHz}, \mathrm{CD}_{2} \mathrm{Cl}_{2}, 223 \mathrm{~K}\right): \delta 0.69,1.30,1.44,1.45$ (m, $3 \mathrm{H}$ each, $\left.\mathrm{P}\left(\mathrm{CH}\left(\mathrm{CH}_{3}\right)_{2}\right)_{2}\right), 1.99\left(\mathrm{~s}, 15 \mathrm{H}, \mathrm{C}_{5}\left(\mathrm{CH}_{3}\right)_{5}\right), 2.47,3.07$ (m, $1 \mathrm{H}$ each, $\left.\mathrm{P}\left(\mathrm{CH}\left(\mathrm{CH}_{3}\right)_{2}\right)_{2}\right), 4.22\left(\mathrm{~d},{ }^{2} J\left(\mathrm{H}_{\jmath} \mathrm{H}_{\mathrm{b}}\right)=21.1 \mathrm{~Hz}, 1 \mathrm{H}\right.$, $\left.\mathrm{Ru} \equiv \mathrm{CCH}_{\mathrm{a}} \mathrm{H}_{\mathrm{b}} \mathrm{C}_{6} \mathrm{H}_{4} \mathrm{CF}_{3}\right), 4.80\left(\mathrm{~d},{ }^{2} J\left(\mathrm{H}_{a}, \mathrm{H}_{\mathrm{b}}\right)=21.1 \mathrm{~Hz}, 1 \mathrm{H}, \mathrm{Ru} \equiv\right.$ $\left.\mathrm{CCH}_{\mathrm{a}} \mathrm{H}_{\mathrm{b}} \mathrm{C}_{6} \mathrm{H}_{4} \mathrm{CF}_{3}\right), 7.18,7.58(\mathrm{~d}, J(\mathrm{H}, \mathrm{H})=7.7 \mathrm{~Hz}, 2 \mathrm{H}$ each, $\left.\mathrm{C}_{6} \mathrm{H}_{4} \mathrm{CF}_{3}\right), 7.01(\mathrm{t}), 7.20(\mathrm{~d}), 7.52(\mathrm{~d}), 7.76(\mathrm{t})\left(1 \mathrm{H}\right.$ each, $\left.\mathrm{C}_{5} \mathrm{H}_{4} \mathrm{~N}\right)$, 7.8 (s br, $1 \mathrm{H}, \mathrm{NH}) .{ }^{31} \mathrm{P}\left\{{ }^{1} \mathrm{H}\right\} \mathrm{NMR}\left(202.31 \mathrm{MHz}, \mathrm{CD}_{2} \mathrm{Cl}_{2}, 223 \mathrm{~K}\right): \delta$ $133.8(\mathrm{~s}) .{ }^{13} \mathrm{C}\left\{{ }^{1} \mathrm{H}\right\}$ NMR $\left(125.67 \mathrm{MHz}, \mathrm{CD}_{2} \mathrm{Cl}_{2}, 223 \mathrm{~K}\right): \delta 10.1(\mathrm{~s}$, $\left.\mathrm{C}_{5}\left(\mathrm{CH}_{3}\right)_{5}\right), 14.6(\mathrm{~s}), 15.1(\mathrm{~s}), 17.1(\mathrm{~s}), 17.5(\mathrm{~s})\left(\mathrm{P}\left(\mathrm{CH}\left(\mathrm{CH}_{3}\right)_{2}\right)_{2}\right), 27.7$ $\left(\mathrm{d},{ }^{1} J(\mathrm{C}, \mathrm{P})=19.7 \mathrm{~Hz}, \mathrm{P}\left(\mathrm{CH}\left(\mathrm{CH}_{3}\right)_{2}\right)\right), 28.7\left(\mathrm{~d},{ }^{1} J(\mathrm{C}, \mathrm{P})=34.9 \mathrm{~Hz}\right.$, $\left.\mathrm{P}\left(\mathrm{CH}\left(\mathrm{CH}_{3}\right)_{2}\right)\right), 61.9\left(\mathrm{~s}, \mathrm{Ru} \equiv \mathrm{CCH}_{2} \mathrm{C}_{6} \mathrm{H}_{4} \mathrm{CF}_{3}\right), 110.7\left(\mathrm{~s}, \mathrm{C}_{5}\left(\mathrm{CH}_{3}\right)_{5}\right)$, 112.6 (d), 119.3 (s), 142.4 (s), 151.7 (s), $162.2(\mathrm{~d})\left(\mathrm{C}_{5} \mathrm{H}_{4} \mathrm{~N}\right), 348.9$ $\left(\mathrm{d},{ }^{2} \mathrm{~J}(\mathrm{C}, \mathrm{P})=12.3 \mathrm{~Hz}, \mathrm{Ru} \equiv \mathrm{C}\right) .{ }^{19} \mathrm{~F}$ NMR $\left(470.17 \mathrm{MHz}, \mathrm{CD}_{2} \mathrm{Cl}_{2}, 223\right.$ $\mathrm{K}): \delta-63.3(\mathrm{~s})$.

2b. ${ }^{1} \mathrm{H}$ NMR ( $\left.500 \mathrm{MHz}, \mathrm{CD}_{2} \mathrm{Cl}_{2}, 223 \mathrm{~K}\right): \delta 0.69,1.29,1.38,1.41$ (m, $3 \mathrm{H}$ each, $\left.\mathrm{P}\left(\mathrm{CH}\left(\mathrm{CH}_{3}\right)_{2}\right)_{2}\right), 1.92\left(\mathrm{~s}, 15 \mathrm{H}, \mathrm{C}_{5}\left(\mathrm{CH}_{3}\right)_{5}\right), 2.47,3.03$ (m, $1 \mathrm{H}$ each, $\left.\mathrm{P}\left(\mathrm{CH}\left(\mathrm{CH}_{3}\right)_{2}\right)_{2}\right), 4.12\left(\mathrm{~d},{ }^{2} J\left(\mathrm{H}_{a}, \mathrm{H}_{\mathrm{b}}\right)=20.6 \mathrm{~Hz}, 1 \mathrm{H}\right.$, $\left.\mathrm{Ru} \equiv \mathrm{CCH}_{\mathrm{a}} \mathrm{H}_{\mathrm{b}} \mathrm{C}_{6} \mathrm{H}_{5}\right), 4.65\left(\mathrm{~d},{ }^{2} J\left(\mathrm{H}_{a} \mathrm{H}_{\mathrm{b}}\right)=20.6 \mathrm{~Hz}, 1 \mathrm{H}, \mathrm{Ru} \equiv\right.$ $\left.\mathrm{CCH}_{\mathrm{a}} \mathrm{H}_{\mathrm{b}} \mathrm{C}_{6} \mathrm{H}_{5}\right), 6.93,7.28,7.57\left(\mathrm{~m}, 5 \mathrm{H}, \mathrm{C}_{6} \mathrm{H}_{5}\right), 7.04(\mathrm{t}), 7.24(\mathrm{~d})$, $7.48(\mathrm{~d}), 7.83(\mathrm{t})\left(1 \mathrm{H}\right.$ each, $\left.\mathrm{C}_{5} \mathrm{H}_{4} \mathrm{~N}\right), 7.70(\mathrm{~s} \mathrm{br}, 1 \mathrm{H}, \mathrm{NH}) .{ }^{31} \mathrm{P}\left\{{ }^{1} \mathrm{H}\right\}$ NMR (202.31 MHz, $\left.\mathrm{CD}_{2} \mathrm{Cl}_{2}, 223 \mathrm{~K}\right): \delta 132.2(\mathrm{~s}) .{ }^{13} \mathrm{C}\left\{{ }^{1} \mathrm{H}\right\} \mathrm{NMR}$ 
$\left(125.67 \mathrm{MHz}, \mathrm{CD}_{2} \mathrm{Cl}_{2}, 233 \mathrm{~K}\right): \delta 10.1\left(\mathrm{~s}, \mathrm{C}_{5}\left(\mathrm{CH}_{3}\right)_{5}\right), 14.6(\mathrm{~s}), 15.2$ (s), $17.1(\mathrm{~s}), 17.4(\mathrm{~s})\left(\mathrm{P}\left(\mathrm{CH}\left(\mathrm{CH}_{3}\right)_{2}\right)_{2}\right), 27.7\left(\mathrm{~d},{ }^{1} \mathrm{~J}(\mathrm{C}, \mathrm{P})=20.8 \mathrm{~Hz}\right.$, $\left.\mathrm{P}\left(\mathrm{CH}\left(\mathrm{CH}_{3}\right)_{2}\right)\right), 28.7\left(\mathrm{~d},{ }^{1} \mathrm{~J}(\mathrm{C}, \mathrm{P})=35.9 \mathrm{~Hz}, \mathrm{P}\left(\mathrm{CH}\left(\mathrm{CH}_{3}\right)_{2}\right)\right), 62.7(\mathrm{~s}$, $\left.\mathrm{Ru} \equiv \mathrm{CCH}_{2} \mathrm{C}_{6} \mathrm{H}_{5}\right), 110.4\left(\mathrm{~s}, \mathrm{C}_{5}\left(\mathrm{CH}_{3}\right)_{5}\right), 113.1(\mathrm{~d}), 119.9$ (s), 143.4 (s), $152.6(\mathrm{~s}), 162.4(\mathrm{~d})\left(\mathrm{C}_{5} \mathrm{H}_{4} \mathrm{~N}\right), 350.8\left(\mathrm{~d},{ }^{2} \mathrm{~J}(\mathrm{C}, \mathrm{P})=12.9 \mathrm{~Hz}, \mathrm{Ru} \equiv\right.$ C).

2c. ${ }^{1} \mathrm{H}$ NMR (500 MHz, $\mathrm{CD}_{2} \mathrm{Cl}_{2}, 223 \mathrm{~K}$ ): $\delta 0.69,1.31,1.40,1.42$ (m, $3 \mathrm{H}$ each, $\left.\mathrm{P}\left(\mathrm{CH}\left(\mathrm{CH}_{3}\right)_{2}\right)_{2}\right), 1.94\left(\mathrm{~s}, 15 \mathrm{H}, \mathrm{C}_{5}\left(\mathrm{CH}_{3}\right)_{5}\right), 2.28$ (s, 3 $\left.\mathrm{H}, \mathrm{C}_{6} \mathrm{H}_{4} \mathrm{CH}_{3}\right), 2.47,3.05\left(\mathrm{~m}, 1 \mathrm{H}\right.$ each, $\left.\mathrm{P}\left(\mathrm{CH}\left(\mathrm{CH}_{3}\right)_{2}\right)_{2}\right), 4.05$ (d, $\left.{ }^{2} J\left(\mathrm{H}_{a}, \mathrm{H}_{\mathrm{b}}\right)=20.7 \mathrm{~Hz}, 1 \mathrm{H}, \mathrm{Ru} \equiv \mathrm{CCH}_{\mathrm{a}} \mathrm{H}_{\mathrm{b}} \mathrm{C}_{6} \mathrm{H}_{4} \mathrm{CH}_{3}\right), 4.58$ (d, $\left.{ }^{2} J\left(\mathrm{H}_{2} \mathrm{H}_{\mathrm{b}}\right)=20.7 \mathrm{~Hz}, 1 \mathrm{H}, \mathrm{Ru} \equiv \mathrm{CCH}_{\mathrm{a}} \mathrm{H}_{\mathrm{b}} \mathrm{C}_{6} \mathrm{H}_{4} \mathrm{CH}_{3}\right), 6.80,7.06(\mathrm{~d}$, ${ }^{3} J(\mathrm{H}, \mathrm{H})=8 \mathrm{~Hz}, 2 \mathrm{H}$ each, $\left.\mathrm{C}_{6} \mathrm{H}_{4} \mathrm{CH}_{3}\right), 7.01(\mathrm{t}), 7.24(\mathrm{~d}), 7.44$ (d), $7.82(\mathrm{t})\left(1 \mathrm{H}\right.$ each, $\left.\mathrm{C}_{5} \mathrm{H}_{4} \mathrm{~N}\right), 7.67(\mathrm{~s}$ br, $1 \mathrm{H}, \mathrm{NH}) .{ }^{31} \mathrm{P}\left\{{ }^{1} \mathrm{H}\right\}$ NMR (202.31 MHz, $\left.\mathrm{CD}_{2} \mathrm{Cl}_{2}, 223 \mathrm{~K}\right): \delta 132.1(\mathrm{~s}) .{ }^{13} \mathrm{C}\left\{{ }^{1} \mathrm{H}\right\}$ NMR $(125.67$ $\left.\mathrm{MHz}, \mathrm{CD}_{2} \mathrm{Cl}_{2}, 233 \mathrm{~K}\right): \delta 10.1\left(\mathrm{~s}, \mathrm{C}_{5}\left(\mathrm{CH}_{3}\right)_{5}\right), 15.5(\mathrm{~s}), 17.6(\mathrm{~s}), 17.8$ $(\mathrm{s}), 17.9(\mathrm{~s})\left(\mathrm{P}\left(\mathrm{CH}\left(\mathrm{CH}_{3}\right)_{2}\right)_{2}\right), 20.8\left(\mathrm{~s} \mathrm{C}_{6} \mathrm{H}_{4} \mathrm{CH}_{3}\right), 27.7\left(\mathrm{~d},{ }^{1} \mathrm{~J}(\mathrm{C}, \mathrm{P})=\right.$ $\left.20.6 \mathrm{~Hz}, \mathrm{P}\left(\mathrm{CH}\left(\mathrm{CH}_{3}\right)_{2}\right)\right), 28.7\left(\mathrm{~d},{ }^{1} \mathrm{~J}(\mathrm{C}, \mathrm{P})=35.7 \mathrm{~Hz}, \mathrm{P}\left(\mathrm{CH}\left(\mathrm{CH}_{3}\right)_{2}\right)\right)$, $62.7\left(\mathrm{~s}, \mathrm{Ru} \equiv \mathrm{CCH}_{2} \mathrm{C}_{6} \mathrm{H}_{4} \mathrm{CH}_{3}\right), 110.3\left(\mathrm{~s}, \mathrm{C}_{5}\left(\mathrm{CH}_{3}\right)_{5}\right), 113.0$ (d), 119.6 (s), $143.2(\mathrm{~s}), 152.2(\mathrm{~s}), 162.4(\mathrm{~d})\left(\mathrm{C}_{5} \mathrm{H}_{4} \mathrm{~N}\right), 350.8\left(\mathrm{~d},{ }^{2} J(\mathrm{C}, \mathrm{P})=11.1\right.$ $\mathrm{Hz}, \mathrm{Ru} \equiv \mathrm{C})$.

2d. ${ }^{1} \mathrm{H}$ NMR ( $\left.500 \mathrm{MHz}, \mathrm{CD}_{2} \mathrm{Cl}_{2}, 223 \mathrm{~K}\right): \delta 0.65,1.26,1.36,1.46$ $\left(\mathrm{m}, 12 \mathrm{H}, \mathrm{P}\left(\mathrm{CH}\left(\mathrm{CH}_{3}\right)_{2}\right)_{2}\right), 1.94\left(\mathrm{~s}, 15 \mathrm{H}, \mathrm{C}_{5}\left(\mathrm{CH}_{3}\right)_{5}\right), 2.43,3.03(\mathrm{~m}, 1$ $\mathrm{H}$ each, $\left.\mathrm{P}\left(\mathrm{CH}\left(\mathrm{CH}_{3}\right)_{2}\right)_{2}\right), 4.04\left(\mathrm{~d},{ }^{2} J\left(\mathrm{H}_{\mathrm{a}}, \mathrm{H}_{\mathrm{b}}\right)=20.7 \mathrm{~Hz}, 1 \mathrm{H}, \mathrm{Ru} \equiv\right.$ $\left.\mathrm{CCH}_{\mathrm{a}} \mathrm{H}_{\mathrm{b}} \mathrm{C}_{6} \mathrm{H}_{4} \mathrm{Br}\right), 4.56\left(\mathrm{~d},{ }^{2} J\left(\mathrm{H}_{2}, \mathrm{H}_{\mathrm{b}}\right)=20.7 \mathrm{~Hz}, 1 \mathrm{H}, \mathrm{Ru} \equiv\right.$ $\left.\mathrm{CCH}_{\mathrm{a}} \mathrm{H}_{\mathrm{b}} \mathrm{C}_{6} \mathrm{H}_{4} \mathrm{Br}\right), 6.85,7.37\left(\mathrm{~d},{ }^{3} \mathrm{~J}(\mathrm{H}, \mathrm{H})=8.4 \mathrm{~Hz}, 2 \mathrm{H}\right.$ each, $\left.\mathrm{C}_{6} \mathrm{H}_{4} \mathrm{Br}\right), 7.00(\mathrm{t}), 7.18(\mathrm{~d}), 7.44(\mathrm{~d}), 7.82(\mathrm{t})\left(1 \mathrm{H}\right.$ each, $\left.\mathrm{C}_{5} \mathrm{H}_{4} \mathrm{~N}\right)$, $7.61(\mathrm{~s} \mathrm{br}, 1 \mathrm{H}, \mathrm{NH}) .{ }^{31} \mathrm{P}\left\{{ }^{1} \mathrm{H}\right\}$ NMR $\left(202.31 \mathrm{MHz}, \mathrm{CD}_{2} \mathrm{Cl}_{2}, 223 \mathrm{~K}\right): \delta$ $132.6(\mathrm{~s}) .{ }^{13} \mathrm{C}\left\{{ }^{1} \mathrm{H}\right\}$ NMR $\left(125.67 \mathrm{MHz}, \mathrm{CD}_{2} \mathrm{Cl}_{2}, 223 \mathrm{~K}\right): \delta 10.1(\mathrm{~s}$, $\left.\mathrm{C}_{5}\left(\mathrm{CH}_{3}\right)_{5}\right), 14.5$ (d), 15.2 (d), 17.1 (s), 17.5 (s) $\left(\mathrm{P}\left(\mathrm{CH}\left(\mathrm{CH}_{3}\right)_{2}\right)_{2}\right)$, $27.7\left(\mathrm{~d},{ }^{1} J(\mathrm{C}, \mathrm{P})=20 \mathrm{~Hz}, \mathrm{P}\left(\mathrm{CH}\left(\mathrm{CH}_{3}\right)_{2}\right)\right), 28.6\left(\mathrm{~d},{ }^{1} J(\mathrm{C}, \mathrm{P})=35.8 \mathrm{~Hz}\right.$, $\left.\mathrm{P}\left(\mathrm{CH}\left(\mathrm{CH}_{3}\right)_{2}\right)\right), 61.8\left(\mathrm{~s}, \mathrm{Ru} \equiv \mathrm{CCH}_{2} \mathrm{C}_{6} \mathrm{H}_{4} \mathrm{Br}\right), 110.6\left(\mathrm{~s}, \mathrm{C}_{5}\left(\mathrm{CH}_{3}\right)_{5}\right)$, 112.7 (d), 119.3 (s), 142.9 (s), $151.6(\mathrm{~s}), 162.3(\mathrm{~d})\left(\mathrm{C}_{5} \mathrm{H}_{4} \mathrm{~N}\right)$, 123.7, 131.1, 133.0, $142.4\left(\mathrm{~s}, \mathrm{C}_{6} \mathrm{H}_{4} \mathrm{Br}\right), 349.3\left(\mathrm{~d},{ }^{2} J(\mathrm{C}, \mathrm{P})=13.7 \mathrm{~Hz}, \mathrm{Ru} \equiv C\right)$.

2e. ${ }^{1} \mathrm{H}$ NMR (400 MHz, $\left.\mathrm{CD}_{2} \mathrm{Cl}_{2}, 233 \mathrm{~K}\right): \delta 0.72,1.35-1.40(\mathrm{~m}, 12$ $\left.\mathrm{H}, \mathrm{P}\left(\mathrm{CH}\left(\mathrm{CH}_{3}\right)_{2}\right)_{2}\right), 0.90\left(\mathrm{~s}, 9 \mathrm{H}, \mathrm{C}\left(\mathrm{CH}_{3}\right)_{3}\right), 2.05(\mathrm{~s}, 15 \mathrm{H}$, $\left.\mathrm{C}_{5}\left(\mathrm{CH}_{3}\right)_{5}\right), 2.50,3.19\left(\mathrm{~m}, 1 \mathrm{H}\right.$ each, $\left.\mathrm{P}\left(\mathrm{CH}\left(\mathrm{CH}_{3}\right)_{2}\right)_{2}\right), 2.86$ (d, $\left.{ }^{2} J\left(\mathrm{H}_{\mathrm{a}} \mathrm{H}_{\mathrm{b}}\right)=20.6 \mathrm{~Hz}, 1 \mathrm{H}, \mathrm{Ru} \equiv \mathrm{CCH}_{\mathrm{a}} \mathrm{H}_{\mathrm{b}} \mathrm{Bu}^{\mathrm{t}}\right), 3.29\left(\mathrm{~d},{ }^{2} J\left(\mathrm{H}_{\mathrm{a}}, \mathrm{H}_{\mathrm{b}}\right)=\right.$ $\left.20.6 \mathrm{~Hz}, 1 \mathrm{H}, \mathrm{Ru} \equiv \mathrm{CCH}_{\mathrm{a}} \mathrm{H}_{\mathrm{b}} \mathrm{Bu}^{\mathrm{t}}\right), 7.18(\mathrm{t}), 7.42(\mathrm{~d}), 7.78(\mathrm{~d}), 7.89(\mathrm{t})$ $\left(1 \mathrm{H}\right.$ each, $\left.\mathrm{C}_{5} \mathrm{H}_{4} \mathrm{~N}\right), 7.99(\mathrm{~s}$ br, $1 \mathrm{H}, \mathrm{NH}) \cdot{ }^{31} \mathrm{P}\left\{{ }^{1} \mathrm{H}\right\}$ NMR $(161.89$ $\left.\mathrm{MHz}, \mathrm{CD}_{2} \mathrm{Cl}_{2}, 233 \mathrm{~K}\right): \delta 130.6(\mathrm{~s}) .{ }^{13} \mathrm{C}\left\{{ }^{1} \mathrm{H}\right\}$ NMR $(100.57 \mathrm{MHz}$, $\left.\mathrm{CDCl}_{3}, 233 \mathrm{~K}\right): \delta 10.5\left(\mathrm{~s}, \mathrm{C}_{5}\left(\mathrm{CH}_{3}\right)_{5}\right), 15.7(\mathrm{~s}), 16.3(\mathrm{~s}), 17.4(\mathrm{~s}), 18.2$ (s) $\left(\mathrm{P}\left(\mathrm{CH}\left(\mathrm{CH}_{3}\right)_{2}\right)_{2}\right), 28.2\left(\mathrm{~d},{ }^{1} \mathrm{~J}(\mathrm{C}, \mathrm{P})=18.9 \mathrm{~Hz}, \mathrm{P}\left(\mathrm{CH}\left(\mathrm{CH}_{3}\right)_{2}\right)\right)$, $29.3\left(\mathrm{~d},{ }^{1} \mathrm{~J}(\mathrm{C}, \mathrm{P})=17.6 \mathrm{~Hz}, \mathrm{P}\left(\mathrm{CH}\left(\mathrm{CH}_{3}\right)_{2}\right)\right), 30.2\left(\mathrm{~s}, \mathrm{CH}_{2} \mathrm{C}\left(\mathrm{CH}_{3}\right)_{3}\right)$,

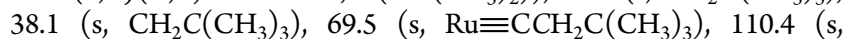
$\left.\mathrm{C}_{5}\left(\mathrm{CH}_{3}\right)_{5}\right), 113.3(\mathrm{~d}), 119.9(\mathrm{~s}), 143.6(\mathrm{~s}), 151.7(\mathrm{~s}), 162.8$ (d) $\left(\mathrm{C}_{5} \mathrm{H}_{4} \mathrm{~N}\right), 363.5\left(\mathrm{~d},{ }^{2} J(\mathrm{C}, \mathrm{P})=11 \mathrm{~Hz}, \mathrm{Ru} \equiv \mathrm{C}\right)$.

2f. ${ }^{1} \mathrm{H}$ NMR (500 MHz, $\mathrm{CD}_{2} \mathrm{Cl}_{2}, 233 \mathrm{~K}$ ): $\delta 0.98,1.34,1.35,1.47$ (m, $3 \mathrm{H}$ each, $\left.\mathrm{P}\left(\mathrm{CH}\left(\mathrm{CH}_{3}\right)_{2}\right)_{2}\right), 2.05\left(\mathrm{~s}, 15 \mathrm{H}, \mathrm{C}_{5}\left(\mathrm{CH}_{3}\right)_{5}\right), 2.60,3.09$ $\left(\mathrm{m}, 1 \mathrm{H}\right.$ each, $\left.\mathrm{P}\left(\mathrm{CH}\left(\mathrm{CH}_{3}\right)_{2}\right)_{2}\right), 3.02\left(\mathrm{~s}, 3 \mathrm{H}, \mathrm{Ru} \equiv \mathrm{CCH}_{3}\right), 7.13(\mathrm{t})$, 7.39 (d), 7.88 (d), 7.96 (t) (1 H each, $\left.\mathrm{C}_{5} \mathrm{H}_{4} \mathrm{~N}\right), 7.75$ (s br, $\left.1 \mathrm{H}, \mathrm{NH}\right)$. ${ }^{31} \mathrm{P}\left\{{ }^{1} \mathrm{H}\right\}$ NMR $\left(202.31 \mathrm{MHz}, \mathrm{CD}_{2} \mathrm{Cl}_{2}, 223 \mathrm{~K}\right): \delta 130.3(\mathrm{~s}) .{ }^{13} \mathrm{C}\left\{{ }^{1} \mathrm{H}\right\}$ NMR (125.67 MHz, $\left.\mathrm{CD}_{2} \mathrm{Cl}_{2}, 223 \mathrm{~K}\right): \delta 10.2\left(\mathrm{~s}, \mathrm{C}_{5}\left(\mathrm{CH}_{3}\right)_{5}\right), 15.6(\mathrm{~s})$, $16.5(\mathrm{~s}), 17.5(\mathrm{~s}), 17.6(\mathrm{~s})\left(\mathrm{P}\left(\mathrm{CH}\left(\mathrm{CH}_{3}\right)_{2}\right)_{2}\right), 28.0\left(\mathrm{~d},{ }^{1} \mathrm{~J}(\mathrm{C}, \mathrm{P})=22.5\right.$ $\left.\mathrm{Hz}, \mathrm{P}\left(\mathrm{CH}\left(\mathrm{CH}_{3}\right)_{2}\right)\right), 29.8\left(\mathrm{~d},{ }^{1} \mathrm{~J}(\mathrm{C}, \mathrm{P})=32 \mathrm{~Hz}, \mathrm{P}\left(\mathrm{CH}\left(\mathrm{CH}_{3}\right)_{2}\right)\right), 45.1$ $\left(\mathrm{s}, \mathrm{Ru} \equiv \mathrm{CCH}_{3}\right), 110.5\left(\mathrm{~s}, \mathrm{C}_{5}\left(\mathrm{CH}_{3}\right)_{5}\right), 113.0(\mathrm{~d}), 119.3$ (s), 143.4 (s), $153.2(\mathrm{~s}), 162.9$ (d) $\left(C_{5} \mathrm{H}_{4} \mathrm{~N}\right), 359.1\left(\mathrm{~d},{ }^{2} J(\mathrm{C}, \mathrm{P})=13.9 \mathrm{~Hz}, \mathrm{Ru} \equiv C\right)$.

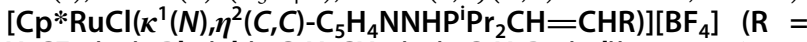
$\mathrm{C}_{6} \mathrm{H}_{4} \mathrm{CF}_{3}$ (3a), $\mathrm{Ph}$ (3b), $\mathrm{C}_{6} \mathrm{H}_{4} \mathrm{CH}_{3}(3 \mathrm{c}), \mathrm{C}_{6} \mathrm{H}_{4} \mathrm{Br}$ (3d)). To a solution of the corresponding vinylidene complex $\mathbf{1 a}-\mathrm{Cl}-\mathbf{1 d}-\mathbf{C l}(0.5 \mathrm{mmol})$ in dichloromethane was added the stoichiometric amount of $\mathrm{HBF}_{4} \cdot \mathrm{OEt}_{2}$ $(69 \mu \mathrm{L})$. The solution changes from red to reddish brown. The mixture was stirred at room temperature for $30 \mathrm{~min}$. Then it was filtered through a plug of anhydrous sodium sulfate, and the solvent was removed in vacuo. The resulting material was successively washed with diethyl ether and petroleum ether until a solid was obtained. The products were recrystallized from dichloromethane/petroleum ether. Microanalysis and X-ray diffraction structure analysis suggest that the complexes are obtained containing one adventitious water molecule of crystallization. 3a. Yield: 0.12 g, 32\%. Anal. Calcd for $\mathrm{C}_{30} \mathrm{H}_{42} \mathrm{~N}_{2} \mathrm{BClF}_{7} \mathrm{OPRu}$ (containing one $\mathrm{H}_{2} \mathrm{O}$ molecule of crystallization): C, 47.54; $\mathrm{H}, 5.59$; $\mathrm{N}$, 3.70. Found: C, 47.60; H, 5.41; N, 3.61. ${ }^{1} \mathrm{H}$ NMR $(400 \mathrm{MHz}$, $\left.\mathrm{CD}_{2} \mathrm{Cl}_{2}, 298 \mathrm{~K}\right): \delta 0.79,1.28,1.69\left(\mathrm{~m}, 12 \mathrm{H}, \mathrm{P}\left(\mathrm{CH}\left(\mathrm{CH}_{3}\right)_{2}\right)_{2}\right), 0.99(\mathrm{~s}$, $\left.15 \mathrm{H}, \mathrm{C}_{5}\left(\mathrm{CH}_{3}\right)_{5}\right), 2.05,3.11\left(\mathrm{~m}, 1 \mathrm{H}\right.$ each, $\left.\mathrm{P}\left(\mathrm{CH}\left(\mathrm{CH}_{3}\right)_{2}\right)_{2}\right), 4.03$ (dd, $\left.{ }^{3} J(\mathrm{H}, \mathrm{H})=12 \mathrm{~Hz},{ }^{3} J(\mathrm{H}, \mathrm{P})=8.6 \mathrm{~Hz}, 1 \mathrm{H}, \mathrm{PCH}=\mathrm{CHC}_{6} \mathrm{H}_{4} \mathrm{CF}_{3}\right), 5.96$ $\left(\mathrm{dd},{ }^{3} \mathrm{~J}(\mathrm{H}, \mathrm{H})=12 \mathrm{~Hz},{ }^{2} J(\mathrm{H}, \mathrm{P})=15.2 \mathrm{~Hz}, 1 \mathrm{H}, \mathrm{PCH}=\mathrm{CHC}_{6} \mathrm{H}_{4} \mathrm{CF}_{3}\right)$, $7.06(\mathrm{t}), 7.45(\mathrm{~d}), 7.69(\mathrm{t}), 8.94(\mathrm{~d})\left(1 \mathrm{H}\right.$ each, $\left.\mathrm{C}_{5} \mathrm{H}_{4} \mathrm{~N}\right), 7.52,7.90(\mathrm{~d}$, ${ }^{3} \mathrm{~J}(\mathrm{H}, \mathrm{H})=8.2 \mathrm{~Hz}, 2 \mathrm{H}$ each, $\left.\mathrm{PCH}=\mathrm{CHC}_{6} \mathrm{H}_{4} \mathrm{CF}_{3}\right), 8.13(\mathrm{~s} \mathrm{br}, 1 \mathrm{H}$, $\mathrm{NH}) .{ }^{31} \mathrm{P}\left\{{ }^{1} \mathrm{H}\right\}$ NMR $\left(161.89 \mathrm{MHz}, \mathrm{CD}_{2} \mathrm{Cl}, 298 \mathrm{~K}\right): \delta 56.7$ (s). ${ }^{13} \mathrm{C}\left\{{ }^{1} \mathrm{H}\right\}$ NMR $\left(100.57 \mathrm{MHz}, \mathrm{CD}_{2} \mathrm{Cl}_{2}, 298 \mathrm{~K}\right): \delta 8.5\left(\mathrm{~s}, \mathrm{C}_{5}\left(\mathrm{CH}_{3}\right)_{5}\right)$, 15.5 (d), 15.8 (s), 17.1 (s), $18.0(\mathrm{~s})\left(\mathrm{P}\left(\mathrm{CH}\left(\mathrm{CH}_{3}\right)_{2}\right)_{2}\right), 21.7\left(\mathrm{~d},{ }^{1} \mathrm{~J}(\mathrm{C}, \mathrm{P})\right.$ $\left.=30 \mathrm{~Hz}, \mathrm{P}\left(\mathrm{CH}\left(\mathrm{CH}_{3}\right)_{2}\right)\right), 22.2\left(\mathrm{~d},{ }^{1} J(\mathrm{C}, \mathrm{P})=32 \mathrm{~Hz}, \mathrm{P}\left(\mathrm{CH}\left(\mathrm{CH}_{3}\right)_{2}\right)\right)$, $31.4\left(\mathrm{~d},{ }^{1} J(\mathrm{C}, \mathrm{P})=80 \mathrm{~Hz}, \mathrm{PCH}=\mathrm{CHC}_{6} \mathrm{H}_{4} \mathrm{CF}_{3}\right), 65.9\left(\mathrm{~d},{ }^{2} \mathrm{~J}(\mathrm{C}, \mathrm{P})=6\right.$ $\left.\mathrm{Hz}, \mathrm{PCH}=\mathrm{CHC}_{6} \mathrm{H}_{4} \mathrm{CF}_{3}\right), 96.2\left(\mathrm{~s}, \mathrm{C}_{5}\left(\mathrm{CH}_{3}\right)_{5}\right), 117.3$ (d), 119.6 (d), $139.9(\mathrm{~s}), 155.1(\mathrm{~s}), 157.8(\mathrm{~d})\left(\mathrm{C}_{5} \mathrm{H}_{4} \mathrm{~N}\right), 125.2,127.4(\mathrm{~s}, \mathrm{PCH}=$ $\left.\mathrm{CHC}_{6} \mathrm{H}_{4} \mathrm{CF}_{3}\right) .{ }^{19} \mathrm{~F}$ NMR $\left(470.17 \mathrm{MHz}, \mathrm{CD}_{2} \mathrm{Cl}_{2}, 298 \mathrm{~K}\right): \delta-63.2(\mathrm{~s})$.

3b. Yield: 0.11 g, 33\%. Anal. Calcd for $\mathrm{C}_{29} \mathrm{H}_{43} \mathrm{~N}_{2} \mathrm{BClF}_{4} \mathrm{OPRu}$ (containing one $\mathrm{H}_{2} \mathrm{O}$ molecule of crystallization): C, 50.48; $\mathrm{H}, 6.28$; $\mathrm{N}, 4.06$. Found: $\mathrm{C}, 50.96 ; \mathrm{H}, 6.18 ; \mathrm{N}, 4.04 .{ }^{1} \mathrm{H}$ NMR $(500 \mathrm{MHz}$, $\left.\mathrm{CD}_{2} \mathrm{Cl}_{2}, 298 \mathrm{~K}\right): \delta 0.85,1.31,1.72\left(\mathrm{~m}, 12 \mathrm{H}, \mathrm{P}\left(\mathrm{CH}\left(\mathrm{CH}_{3}\right)_{2}\right)_{2}\right), 1.02(\mathrm{~s}$, $\left.15 \mathrm{H}, \mathrm{C}_{5}\left(\mathrm{CH}_{3}\right)_{5}\right), 2.11,3.25\left(\mathrm{~m}, 1 \mathrm{H}\right.$ each, $\left.\mathrm{P}\left(\mathrm{CH}\left(\mathrm{CH}_{3}\right)_{2}\right)_{2}\right), 4.13$ (dd, $\left.{ }^{3} J(\mathrm{H}, \mathrm{H})=11.9 \mathrm{~Hz},{ }^{3} J(\mathrm{H}, \mathrm{P})=9.3 \mathrm{~Hz}, 1 \mathrm{H}, \mathrm{PCH}=\mathrm{CHC}_{6} \mathrm{H}_{5}\right), 5.99$ $\left(\mathrm{dd},{ }^{3} J(\mathrm{H}, \mathrm{H})=11.9 \mathrm{~Hz},{ }^{2} J(\mathrm{H}, \mathrm{P})=15.7 \mathrm{~Hz}, 1 \mathrm{H}, \mathrm{PCH}=\mathrm{CHC}_{6} \mathrm{H}_{5}\right)$, $7.06(\mathrm{t}), 7.24(\mathrm{~d}), 7.71(\mathrm{t}), 8.99$ (d) $\left(1 \mathrm{H}\right.$ each, $\left.\mathrm{C}_{5} \mathrm{H}_{4} \mathrm{~N}\right), 7.27,7.89(\mathrm{~m}$, $\left.5 \mathrm{H}, \mathrm{PCH}=\mathrm{CHC}_{6} H_{5}\right), 8.37($ br, $1 \mathrm{H}, \mathrm{NH}) .{ }^{31} \mathrm{P}\left\{{ }^{1} \mathrm{H}\right\}$ NMR $(202.31$ $\left.\mathrm{MHz}, \mathrm{CD}_{2} \mathrm{Cl}, 298 \mathrm{~K}\right): \delta 55.0(\mathrm{~s}) .{ }^{13} \mathrm{C}\left\{{ }^{1} \mathrm{H}\right\}$ NMR $(125.67 \mathrm{MHz}$, $\left.\mathrm{CD}_{2} \mathrm{Cl}_{2}, 298 \mathrm{~K}\right): \delta 8.4\left(\mathrm{~s}, \mathrm{C}_{5}\left(\mathrm{CH}_{3}\right)_{5}\right), 15.2,15.9,17.5,17.8(\mathrm{~s}$, $\left.\mathrm{P}\left(\mathrm{CH}\left(\mathrm{CH}_{3}\right)_{2}\right)_{2}\right), 21.8\left(\mathrm{~d},{ }^{1} \mathrm{~J}(\mathrm{C}, \mathrm{P})=52.2 \mathrm{~Hz}, \mathrm{P}\left(\mathrm{CH}\left(\mathrm{CH}_{3}\right)_{2}\right)\right), 22.1(\mathrm{~d}$, $\left.{ }^{1} J(\mathrm{C}, \mathrm{P})=53.2 \mathrm{~Hz}, \mathrm{P}\left(\mathrm{CH}\left(\mathrm{CH}_{3}\right)_{2}\right)\right), 31.5\left(\mathrm{~d},{ }^{1} J(\mathrm{C}, \mathrm{P})=80.3 \mathrm{~Hz}\right.$, $\left.\mathrm{PCH}=\mathrm{CHC}_{6} \mathrm{H}_{5}\right), 68.3\left(\mathrm{~d},{ }^{2} \mathrm{~J}(\mathrm{C}, \mathrm{P})=6 \mathrm{~Hz}, \mathrm{PCH}=\mathrm{CHC}_{6} \mathrm{H}_{5}\right), 95.3(\mathrm{~s}$, $\left.\mathrm{C}_{5}\left(\mathrm{CH}_{3}\right)_{5}\right), 117.4(\mathrm{~d}), 119.1(\mathrm{~s}), 139.4(\mathrm{~s}), 155.0(\mathrm{~s}), 158.2$ (d) $\left(\mathrm{C}_{5} \mathrm{H}_{4} \mathrm{~N}\right), 126.9,127.1,128.1,129.3\left(\mathrm{~s}, \mathrm{PCH}=\mathrm{CHC}_{6} \mathrm{H}_{5}\right)$.

3c. Yield: 0.11 g, 32\%. Anal. Calcd for $\mathrm{C}_{30} \mathrm{H}_{45} \mathrm{~N}_{2} \mathrm{BClF}_{4} \mathrm{OPRu}$ (containing one $\mathrm{H}_{2} \mathrm{O}$ molecule of crystallization): C, 51.18; H, 6.44; $\mathrm{N}$, 3.98. Found: C, 51.28; H, 6.39; N, 3.91. ${ }^{1} \mathrm{H}$ NMR $(400 \mathrm{MHz}$, $\left.\mathrm{CD}_{2} \mathrm{Cl}_{2}, 298 \mathrm{~K}\right): \delta 0.80,1.28,1.68\left(\mathrm{~m}, 12 \mathrm{H}, \mathrm{P}\left(\mathrm{CH}\left(\mathrm{CH}_{3}\right)_{2}\right)_{2}\right), 0.99(\mathrm{~s}$, $\left.15 \mathrm{H}, \mathrm{C}_{5}\left(\mathrm{CH}_{3}\right)_{5}\right), 2.05,2.25\left(\mathrm{~m}, 1 \mathrm{H}\right.$ each, $\left.\mathrm{P}\left(\mathrm{CH}\left(\mathrm{CH}_{3}\right)_{2}\right)_{2}\right), 2.28(\mathrm{~s}, 3$ $\left.\mathrm{H}, \mathrm{PCH}=\mathrm{CHC}_{6} \mathrm{H}_{4} \mathrm{CH}_{3}\right), 4.08\left(\mathrm{dd},{ }^{3} \mathrm{~J}(\mathrm{H}, \mathrm{H})=12 \mathrm{~Hz},{ }^{3} \mathrm{~J}(\mathrm{H}, \mathrm{P})=9 \mathrm{~Hz}\right.$, $\left.1 \mathrm{H}, \mathrm{PCH}=\mathrm{CHC}_{6} \mathrm{H}_{4} \mathrm{CH}_{3}\right), 5.96\left(\mathrm{dd},{ }^{3} \mathrm{~J}(\mathrm{H}, \mathrm{H})=12 \mathrm{~Hz},{ }^{2} \mathrm{~J}(\mathrm{H}, \mathrm{P})=16\right.$ $\left.\mathrm{Hz}, 1 \mathrm{H}, \mathrm{PCH}=\mathrm{CHC}_{6} \mathrm{H}_{4} \mathrm{CH}_{3}\right), 7.05(\mathrm{t}), 7.64(\mathrm{~m}), 8.96(\mathrm{~d})(4 \mathrm{H}$, $\left.\mathrm{C}_{5} \mathrm{H}_{4} \mathrm{~N}\right), 7.10,7.65\left(\mathrm{~d},{ }^{3} \mathrm{~J}(\mathrm{H}, \mathrm{H})=9 \mathrm{~Hz}, 2 \mathrm{H}\right.$ each, $\mathrm{PCH}=$ $\left.\mathrm{CHC}_{6} \mathrm{H}_{4} \mathrm{CH}_{3}\right), 8.13(\mathrm{~s}$ br, $1 \mathrm{H}, \mathrm{NH}) .{ }^{31} \mathrm{P}\left\{{ }^{1} \mathrm{H}\right\} \mathrm{NMR}(161.89 \mathrm{MHz}$, $\left.\mathrm{CD}_{2} \mathrm{Cl}, 298 \mathrm{~K}\right): \delta 56.2(\mathrm{~s}) .{ }^{13} \mathrm{C}\left\{{ }^{1} \mathrm{H}\right\}$ NMR $\left(100.57 \mathrm{MHz}, \mathrm{CD}_{2} \mathrm{Cl}_{2}, 298\right.$ $\mathrm{K}): \delta 8.5\left(\mathrm{~s}, \mathrm{C}_{5}\left(\mathrm{CH}_{3}\right)_{5}\right), 15.8(\mathrm{~d}), 17.1(\mathrm{~s}), 17.3(\mathrm{~d}), 18.1(\mathrm{~s})$ $\left(\mathrm{P}\left(\mathrm{CH}\left(\mathrm{CH}_{3}\right)_{2}\right)_{2}\right), 21.3\left(\mathrm{~s}, \mathrm{PCH}=\mathrm{CHC}_{6} \mathrm{H}_{4} \mathrm{CH}_{3}\right), 21.7\left(\mathrm{~d},{ }^{1} \mathrm{~J}(\mathrm{C}, \mathrm{P})=\right.$ $\left.32 \mathrm{~Hz}, \mathrm{P}\left(\mathrm{CH}\left(\mathrm{CH}_{3}\right)_{2}\right)\right), 22.0\left(\mathrm{~d},{ }^{1} J(\mathrm{C}, \mathrm{P})=33 \mathrm{~Hz}, \mathrm{P}\left(\mathrm{CH}\left(\mathrm{CH}_{3}\right)_{2}\right)\right)$, $31.7\left(\mathrm{~d},{ }^{1} J(\mathrm{C}, \mathrm{P})=80 \mathrm{~Hz}, \mathrm{PCH}=\mathrm{CHC}_{6} \mathrm{H}_{4} \mathrm{CH}_{3}\right), 69.0\left(\mathrm{~d},{ }^{2} J(\mathrm{C}, \mathrm{P})=6\right.$ $\left.\mathrm{Hz}, \mathrm{PCH}=\mathrm{CHC}_{6} \mathrm{H}_{4} \mathrm{CH}_{3}\right), 95.3\left(\mathrm{~s}, \mathrm{C}_{5}\left(\mathrm{CH}_{3}\right)_{5}\right), 117.3$ (d), 119.2 (d), $139.6(\mathrm{~s}), 155.1(\mathrm{~s}), 158.2(\mathrm{~d})\left(\mathrm{C}_{5} \mathrm{H}_{4} \mathrm{~N}\right), 127.2,128.9,130.9,137.1$ (s, $\left.\mathrm{PCH}=\mathrm{CHC}_{6} \mathrm{H}_{4} \mathrm{CH}_{3}\right)$.

3d. Yield: 0.11 g, 29\%. Anal. Calcd for $\mathrm{C}_{29} \mathrm{H}_{42} \mathrm{~N}_{2} \mathrm{BBrClF}_{4} \mathrm{OPRu}$ (containing one $\mathrm{H}_{2} \mathrm{O}$ molecule of crystallization): C, 45.30; $\mathrm{H}, 5.51$; $\mathrm{N}$, 3.64. Found: C, 45.50; H, 5.59; N, 3.54. ${ }^{1} \mathrm{H}$ NMR $(400 \mathrm{MHz}$, $\left.\mathrm{CD}_{2} \mathrm{Cl}_{2}, 298 \mathrm{~K}\right): \delta 0.86,1.36,1.77\left(\mathrm{~m}, 12 \mathrm{H}, \mathrm{P}\left(\mathrm{CH}\left(\mathrm{CH}_{3}\right)_{2}\right)_{2}\right), 1.10(\mathrm{~s}$, $\left.15 \mathrm{H}, \mathrm{C}_{5}\left(\mathrm{CH}_{3}\right)_{5}\right), 2.25,3.28\left(\mathrm{~m}, 1 \mathrm{H}\right.$ each, $\left.\mathrm{P}\left(\mathrm{CH}\left(\mathrm{CH}_{3}\right)_{2}\right)_{2}\right), 4.44$ (dd, $\left.{ }^{3} J(\mathrm{H}, \mathrm{H})=12 \mathrm{~Hz},{ }^{3} \mathrm{~J}(\mathrm{H}, \mathrm{P})=10 \mathrm{~Hz}, 1 \mathrm{H}, \mathrm{PCH}=\mathrm{CHC}_{6} \mathrm{H}_{4} \mathrm{Br}\right), 5.87$ $\left(\mathrm{dd},{ }^{3} J(\mathrm{H}, \mathrm{H})=12 \mathrm{~Hz},{ }^{2} J(\mathrm{H}, \mathrm{P})=16 \mathrm{~Hz}, 1 \mathrm{H}, \mathrm{PCH}=\mathrm{CHC}_{6} \mathrm{H}_{4} \mathrm{Br}\right)$, $7.20(\mathrm{t}), 7.45(\mathrm{~d}), 7.82(\mathrm{t}), 8.85(\mathrm{~d})\left(1 \mathrm{H}\right.$ each, $\left.\mathrm{C}_{5} \mathrm{H}_{4} \mathrm{~N}\right), 7.38,7.88(\mathrm{~d}$, ${ }^{3} J(\mathrm{H}, \mathrm{H})=9 \mathrm{~Hz}, 2 \mathrm{H}$ each, $\left.\mathrm{PCH}=\mathrm{CHC}_{6} \mathrm{H}_{4} \mathrm{Br}\right), 8.31\left(\mathrm{~d}\right.$ br, ${ }^{2} J(\mathrm{H}, \mathrm{P})=$ $8 \mathrm{~Hz}, 1 \mathrm{H}, \mathrm{NH}) .{ }^{31} \mathrm{P}\left\{{ }^{1} \mathrm{H}\right\}$ NMR $\left(161.89 \mathrm{MHz}, \mathrm{CD}_{2} \mathrm{Cl}, 298 \mathrm{~K}\right): \delta 57.1$ (s). ${ }^{13} \mathrm{C}\left\{{ }^{1} \mathrm{H}\right\}$ NMR $\left(100.57 \mathrm{MHz}, \mathrm{CD}_{3} \mathrm{COCD}_{3}, 298 \mathrm{~K}\right): \delta 8.6(\mathrm{~s}$, $\left.\mathrm{C}_{5}\left(\mathrm{CH}_{3}\right)_{5}\right), 15.9,16.2,17.1,17.9\left(\mathrm{~s}, \mathrm{P}\left(\mathrm{CH}\left(\mathrm{CH}_{3}\right)_{2}\right)_{2}\right), 22.2\left(\mathrm{~d},{ }^{1} \mathrm{~J}(\mathrm{C}, \mathrm{P})\right.$ $\left.=32 \mathrm{~Hz}, \mathrm{P}\left(\mathrm{CH}\left(\mathrm{CH}_{3}\right)_{2}\right)\right), 23.0\left(\mathrm{~d},{ }^{1} \mathrm{~J}(\mathrm{C}, \mathrm{P})=33 \mathrm{~Hz}, \mathrm{P}\left(\mathrm{CH}\left(\mathrm{CH}_{3}\right)_{2}\right)\right)$, $31.7\left(\mathrm{~d},{ }^{1} J(\mathrm{C}, \mathrm{P})=78 \mathrm{~Hz}, \mathrm{PCH}=\mathrm{CHC}_{6} \mathrm{H}_{4} \mathrm{Br}\right), 67.1\left(\mathrm{~d},{ }^{2} \mathrm{~J}(\mathrm{C}, \mathrm{P})=6\right.$ $\left.\mathrm{Hz}, \mathrm{PCH}=\mathrm{CHC}_{6} \mathrm{H}_{4} \mathrm{Br}\right), 96.1\left(\mathrm{~s}, \mathrm{C}_{5}\left(\mathrm{CH}_{3}\right)_{5}\right), 117.0(\mathrm{~d}), 119.4(\mathrm{~s})$, $139.9(\mathrm{~s}), 155.3(\mathrm{~s}), 158.0(\mathrm{~d})\left(\mathrm{C}_{5} \mathrm{H}_{4} \mathrm{~N}\right), 119.8,129.3,130.6,130.8(\mathrm{~s}$, $\mathrm{PCH}=\mathrm{CHC}_{6} \mathrm{H}_{4} \mathrm{Br}$ ). 
Computational Details. All calculations were performed at the DFT level using the PBE0 functional ${ }^{30}$ as implemented in Gaussian 09. ${ }^{31}$ This functional performs well for second-row transition-metal complexes $^{32}$ and correctly describes agostic interactions. ${ }^{33}$ The $\mathrm{Ru}$ atom was described using the scalar-relativistic Stuttgart-Dresden SDD pseudopotential ${ }^{34}$ and its associated double- $\zeta$ basis set complemented with a set of f-polarization functions. ${ }^{35}$ The $6-31 G^{* *}$ basis set was used for the $\mathrm{H}^{36} \mathrm{C}, \mathrm{N}, \mathrm{F}, \mathrm{P}$, and $\mathrm{Cl}$ atoms. ${ }^{37}$ Diffuse functions were added for $\mathrm{F}$ and $\mathrm{Cl}$ atoms ${ }^{38}$ in all calculations. Dichloromethane $(\mathrm{DCM})$ solvent effects $(\varepsilon=8.93)$ were calculated through continuum $\mathrm{SMD}^{39}$ single-point calculations on gas-phase optimized geometries. Transition states were identified by having one imaginary frequency in the Hessian matrix. It was confirmed that transition states connect with the corresponding intermediates by means of application of the eigenvector corresponding to the imaginary frequency and subsequent optimization of the resulting structures. Gibbs energies in DCM solution, $\Delta G_{\mathrm{DCM}}$, were computed according to the expression

$$
\Delta G_{\mathrm{DCM}}=\Delta E_{\mathrm{DCM}}+\Delta G_{\mathrm{gp}}-\Delta E_{\mathrm{gp}}
$$

where the gp subscript indicates gas phase.

X-ray Structure Determinations. Crystals of 3d were obtained by recrystallization from dichloromethane/petroleum ether in the form of a monohydrate. Crystal data and experimental details are given in Table S1 in the Supporting Information. X-ray diffraction data were collected on a three-circle diffractometer with CCD area detector at the Servicio Central de Ciencia y Tecnología de la Universidad de Cádiz, using Mo $\mathrm{K} \alpha$ radiation $(\lambda=071073 \AA)$. Hemispheres of the reciprocal space were measured by $\omega$ scan frames with $\delta(\omega) 0.30^{\circ}$. Correction for absorption and crystal decay (insignificant) were applied by semiempirical methods from equivalents using the program SADABS. ${ }^{40}$ The structures were solved by direct methods, completed by subsequent difference Fourier synthesis and refined on $F^{2}$ by fullmatrix least-squares procedures using the SHELXTL program suite. ${ }^{41}$ All non-hydrogen atoms except disordered oxygen atoms in the solvate were refined with anisotropic displacement coefficients. Water $\mathrm{O} 1$ was found to be disordered, and it was modeled over three positions, O1A (sof 0.49), O1B (sof 0.31), and O1C (sof 0.21); these oxygen atoms were isotropically refined. The hydrogen atoms were calculated at idealized positions and refined using the SHELX riding model. The program ORTEP- $3^{42}$ was used for plotting.

\section{ASSOCIATED CONTENT}

\section{(5) Supporting Information}

CIF and xyz files, text, tables, and figures giving crystallographic data for compound $\mathbf{3 d}$ (this crystal structure has been also deposited at Cambridge Crystallographic Data System with reference CCDC 982618), crystal data and experimental details for the crystal structure determination (Table S1), details of DFT calculations considering a nucleophilic attack of phosphorus from $7 \mathbf{a}$ and an alternative $\mathrm{P}, \mathrm{N}$-ligand conformation, and Cartesian coordinates and energies (hartrees) of all the calculated species. This material is available free of charge via the Internet at http://pubs.acs.org.

\section{AUTHOR INFORMATION}

\section{Corresponding Authors}

*E-mail for M.J.-T.: manuel.tenorio@uca.es.

*E-mail for M.C.P.: carmen.puerta@uca.es.

*E-mail for A.L.: agusti@klingon.uab.es.

\section{Notes}

The authors declare no competing financial interest.

\section{ACKNOWLEDGMENTS}

We thank the Spanish Ministerio de Economia y Competitividad (Projects CTQ2010-15390 and CTQ2011-23336) and Junta de
Andalucía (PAIDI FQM188, P08 FQM 03538) for financial support and Johnson Matthey plc for generous loans of ruthenium trichloride. M.A.O. thanks the Spanish MECD for a research grant. The collaboration of Ph.D. Ignacio Macias-Arce on the early experimental stages of the present work is gratefully acknowledged.

\section{REFERENCES}

(1) (a) Shi, C.; Jia, G. Coord. Chem. Rev. 2013, 257, 666-701 and references therein. (b) Jia, G. Coord. Chem. Rev. 2007, 251, 21672187. (c) Transition Metal Carbyne Complexes. In NATO ASI Series, Series C: Mathematical and Physical Sciences; Kreissl, F. R., Ed.; Kluwer Academic: Dordrecht, The Netherlands, 1993; Vol. 392. (d) Fischer, E. O.; Hofman, P.; Kreissl, F. R.; Schrock, R. R; Schubert, U.; Weiss, K. Carbyne Complexes; VCH: Weinheim, Germany, 1988.

(2) (a) Chen, J.; He, C.; Sung, H. H. Y.; Williams, I. D.; Lin, Z.; Jia, G. Organometallics 2010, 29, 2693-2701. (b) Carvalho, M. F. N. N.; Almeida, S. S. P. R.; Pombeiro, A. J. L.; Henderson, R. A. Organometallics 1997, 16, 5441-5448.

(3) See for instance: Shao, M.; Zheng, L.; Qiao, W.; Wang, J.; Wang, J. Adv. Synth. Catal. 2012, 354, 2743-2750 and references therein.

(4) (a) Bolaño, T.; Esteruelas, M. A.; Oñate, E. J. Organomet. Chem. 2011, 696, 3911-3923. (b) Chen, J.; Sung, H. H.; Williams, I. D.; Jia, G. Organometallics 2011, 30, 6159-6165. (c) Richter, B.; Werner, H. Organometallics 2009, 28, 5137-5141. (d) Castarlenas, R; Esteruelas, M. A.; Oñate, E. Organometallics 2007, 26, 2129-2132. (e) Stewart, M. H.; Johnson, M. J. A.; Kampf, J. W. Organometallics 2007, 26, 5102-5110. (f) Esteruelas, M. A.; Gonzalez, A. I.; López, A. M.; Oñate, E. Organometallics 2003, 22, 414-425. (g) Wen, T. B.; Cheung, Y. K.; Yao, J.; Wong, W.; Zhou, Z. Y.; Jia, G. Organometallics 2000, 19, 3803-3809.

(5) (a) Caulton, K. G. J. Organomet. Chem. 2001, 617-618, 56-64. (b) LaPointe, A. M.; Schrock, R. R.; Davis, W. M. J. Am. Chem. Soc. 1995, 117, 4802-4813.

(6) González-Herrero, P.; Weberndorfer, B.; Ilg, K.; Werner, H. Angew. Chem., Int. Ed. 2000, 39, 3266-3269.

(7) (a) Jung, S.; Ilg, K.; Brandt, C. D.; Wolf, J.; Werner, H. Eur. J. Inorg. Chem. 2004, 469-480. (b) González-Herrero, P.; Weberndorfer, B.; Ilg, K.; Werner, H. Organometallics 2001, 20, 3672-3685.

(8) Beach, J. B.; Jenkins, H. A.; Spivak, G. J. Organometallics 2003, 22, 5179-5181.

(9) Bustelo, E.; Jiménez-Tenorio, M.; Puerta, M. C.; Valerga, P.; Mereiter, K. Organometallics 2002, 21, 1903-1911.

(10) Pino-Chamorro, J. A.; Bustelo, E.; Puerta, M. C.; Valerga, P. Organometallics 2009, 28, 1546-1557.

(11) Arikawa, Y.; Yamasaki, H.; Yamaguchi, M.; Umakoshi, K.; Onishi, M. Organometallics 2009, 28, 5587-5589.

(12) Caskey, S. R.; Stewart, M. H.; Ahn, Y. J.; Johnson, M. J. A.; Rowsell, J. L. C.; Kampf, J. W. Organometallics 2007, 26, 1912-1923.

(13) Jiménez-Tenorio, M.; Puerta, M. C.; Valerga, P.; Ortuño, M. A.; Ujaque, G.; Lledós, A. Inorg. Chem. 2013, 52, 8919-8932.

(14) (a) Bustelo, E.; Jiménez-Tenorio, M.; Puerta, M. C.; Valerga, P. Organometallics 2007, 26, 4300-4309. (b) Bustelo, E.; JiménezTenorio, M.; Puerta, M. C.; Valerga, P. Organometallics 2006, 25, 4019-4025.

(15) (a) Grotjahn, D. B. Chem. Eur. J. 2005, 11, 7146-7153. (b) Grotjahn, D. B. Dalton Trans. 2008, 6497-6508.

(16) (a) Fernandez, F.; Puerta, M. C.; Valerga, P. Inorg. Chem. 2013, 52, 4396-4410. (b) Ura, Y.; Tsunawaki, F.; Wada, K.; Shiotsuki, M.; Kondo, T.; Yamaguchi, S.; Masuda, H.; Ohnishi, A.; Mitsudo, T. Organometallics 2005, 24, 5724-5731. (c) Rüba, E.; Gemel, C.; Slugovc, C.; Mereiter, K.; Schmid, R.; Kirchner, K. Organometallics 1999, 18, 2275-2280.

(17) Onitsuka, K.; Nishii, M.; Matsushima, Y.; Takahashi, S. Organometallics 2004, 23, 5630-5632.

(18) Macías-Arce, I.; Puerta, M. C.; Valerga, P. Eur. J. Inorg. Chem. 2010, 1767-1776. 
(19) Metal Vinylidenes and Allenylidenes in Catalysis: From Reactivity to Applications in Synthesis; Bruneau, C., Dixneuf, P. H., Eds.; WileyVCH: Weinheim, Germany, 2008.

(20) Jiménez-Tenorio, M.; Puerta, M. C.; Valerga, P.; Moncho, S.; Ujaque, G.; Lledós, A. Inorg. Chem. 2010, 49, 6035-6057.

(21) (a) Seebach, D. Angew. Chem., Int. Ed. 1979, 18, 239-258.

(b) Gröbel, B. T.; Seebach, D. Synthesis 1977, 6, 357-402.

(22) The geometry optimizations of $7 \mathbf{a}$ and $7 \mathbf{a}^{\prime}$ in the gas phase lead to the formation of $\mathrm{NH} \cdots \mathrm{HCl}$ adducts rather than $\mathrm{NH}_{2}^{+} \cdots \mathrm{Cl}^{-}$. To properly describe the charged species, optimizations in DCM solvent have been performed for this particular situation. The resulting values of $12.0 \mathrm{kcal} \mathrm{mol}^{-1}$ for $7 \mathbf{a}$ and $11.7 \mathrm{kcal} \mathrm{mol}^{-1}$ for $7 \mathbf{a}^{\prime}$ may be overestabilized with respect to the single-point correction performed on the gas-phase geometry of $4 \mathbf{a}$ (zero energy).

(23) For unsaturated intermediates 11a, the vacant site is fulfilled by agostic interactions involving one hydrogen of the aryl group in 11 ac $(\mathrm{Ru} \cdots \mathrm{H}$ distance of $1.997 \AA)$ and one hydrogen of the $\beta$-carbon in 11at $(\mathrm{Ru} \cdots \mathrm{H}$ distance of $2.611 \AA)$.

(24) Indeed this happens for route a, where the Gibbs energy differences between proton transfer transition states, TS5a-6a and TS5 $\mathbf{a}^{\prime}{ }^{-6} \mathbf{a}^{\prime}$, and hydride intermediates, $\mathbf{6 a}$ and $\mathbf{6} \mathbf{a}^{\prime}$, are 0.2 and $1.4 \mathrm{kcal}$ $\mathrm{mol}^{-1}$.

(25) Besora, M.; Lledós, A.; Maseras, F. Chem. Soc. Rev. 2009, 38, 957-966.

(26) (a) Macchioni, A. Chem. Rev. 2005, 105, 2039-2073. (b) Clot, E. Eur. J. Inorg. Chem. 2009, 2319-2328.

(27) (a) Basallote, M. G.; Besora, M.; Castillo, C. E.; FernándezTrujillo, M. J.; Lledós, A.; Maseras, F.; Máñez, M. A. J. Am. Chem. Soc. 2007, 129, 6608-6618. (b) Kovács, G.; Ujaque, G.; Lledós, A. J. Am. Chem. Soc. 2008, 130, 853-864.

(28) (a) Appelhans, L. N.; Zuccaccia, D.; Kovacevic, D.; Chianese, A. R.; Miecznikowski, J. R.; Macchioni, A.; Clot, E.; Eisenstein, O.; Crabtree, R. H. J. Am. Chem. Soc. 2005, 127, 16299-16311. (b) Xia, Y.; Dubnik, A. S.; Gevorgyan, V.; Li, Y. J. Am. Chem. Soc. 2008, 130, 6940-6941. (c) Boutadla, Y.; Davies, D. L.; Macgregor, S. A.; Poblador-Bahamonde, A. I. Dalton Trans. 2009, 5820-5831.

(29) Steinmetz, B.; Schenk, W. A. Organometallics 1999, 18, 943946.

(30) (a) Perdew, J. P.; Burke, K.; Ernzerhof, M. Phys. Rev. Lett. 1996, 77, 3865-3868. (b) Perdew, J. P.; Ernzerhof, M.; Burke, K. J. Chem. Phys. 1996, 105, 9982-9985.

(31) Frisch, M. J.; Trucks, G. W.; Schlegel, H. B.; Scuseria, G. E.; Robb, M. A.; Cheeseman, J. R.; Scalmani, G.; Barone, V.; Mennucci, B.; Petersson, G. A.; Nakatsuji, H.; Caricato, M.; Li, X.; Hratchian, H. P.; Izmaylov, A. F.; Bloino, J.; Zheng, G.; Sonnenberg, J. L.; Hada, M.; Ehara, M.; Toyota, K.; Fukuda, R.; Hasegawa, J.; Ishida, M.; Nakajima, T.; Honda, Y.; Kitao, O.; Nakai, H.; Vreven, T.; Montgomery, J. A., Jr.; Peralta, J. E.; Ogliaro, F.; Bearpark, M.; Heyd, J. J.; Brothers, E.; Kudin, K. N.; Staroverov, V. N.; Kobayashi, R.; Normand, J.; Raghavachari, K.; Rendell, A.; Burant, J. C.; Iyengar, S. S.; Tomasi, J.; Cossi, M.; Rega, N.; Millam, J. M.; Klene, M.; Knox, J. E.; Cross, J. B.; Bakken, V.; Adamo, C.; Jaramillo, J.; Gomperts, R.; Stratmann, R. E.; Yazyev, O.; Austin, A. J.; Cammi, R.; Pomelli, C.; Ochterski, J. W.; Martin, R. L.; Morokuma, K.; Zakrzewski, V. G.; Voth, G. A.; Salvador, P.; Dannenberg, J. J.; Dapprich, S.; Daniels, A. D.; Ö. Farkas, Foresman, J. B.; Ortiz, J. V.; Cioslowski, J.; , and Fox, D. J. Gaussian 09, Revision A.1; Gaussian, Inc., Wallingford, CT, 2009.

(32) (a) Quintal, M. M.; Karton, A.; Iron, M. A.; Boese, A. D.; Martin, J. M. L. J. Phys. Chem. A 2006, 110, 709-716. (b) Waller, M. P.; Braun, H.; Hojdis, N.; Bühl, M. J. Chem. Theory. Comp. 2007, 3, 2234-2242.

(33) Pantazis, D. A.; McGrady, J. E.; Maseras, F.; Etienne, M. J. Chem. Theory Comput. 2007, 3, 1329-1336.

(34) Andrae, D.; Haeussermann, U.; Dolg, M.; Stoll, H.; Preuss, H. Theor. Chim. Acta 1990, 77, 123-141.

(35) Ehlers, A. W.; Bohme, M.; Dapprich, S.; Gobbi, A.; Hollwarth, A.; Jonas, V.; Kohler, K. F.; Stegmann, R.; Veldkamp, A.; Frenking, G. Chem. Phys. Lett. 1993, 208, 111-114.
(36) Hehre, W. J.; Ditchfield, R.; Pople, J. A. J. Chem. Phys. 1972, 56, 2257-2261.

(37) Francl, M. M.; Pietro, W. J.; Hehre, W. J.; Binkley, J. S.; Gordon, M. S.; DeFrees, D. J.; Pople, J. A. J. Chem. Phys. 1982, 77, 3654-3665.

(38) Clark, T.; Chandrasekhar, J.; Spitznagel, G. W.; Schleyer, P. J. Comput. Chem. 1983, 4, 294-301.

(39) Marenich, A. V.; Cramer, C. J.; Truhlar, D. G. J. Phys. Chem. B 2009, 113, 6378-6396.

(40) Sheldrick, G. M. SADABS; University of Göttingen, Göttingen, Germany, 2001.

(41) Sheldrick, G. M. SHELXTL version 6.10, Crystal Structure Analysis Package; Bruker AXS, Madison, WI, 2000.

(42) Farrugia, L. J. ORTEP-3 for Windows, version 1.076. J. Appl. Crystallogr. 1997, 30, 565. 